\title{
KOROLEVO CASTLE OF NYALÁB
}

\author{
IGOR PROKHNENKO - MARIA ZHYLENKO - VOLODIMIR MOIZHES
}

\begin{abstract}
The castle of Nyaláb is located near the village of Korolevo, the Vynohradiv district of Zakarpats'ka oblast of Ukraine. It is distinguished by a very rich cultural layer, a complex stratigraphy and a significant number of finds. Three residential rooms were investigated, the construction of four tile stoves was studied, and thousands of samples of ceramics, stove-tiles, leather, bones, glass and metal products were excavated on the site by an expedition of Uzhhorod National University during the field seasons of 2007, 2011-2014. The general dating of the finds is the end of the 13th-mid-17th centuries.
\end{abstract}

Key words: Korolevo - castle of Nyaláb - tile-stove - ceramics - stove-tiles.

\section{Hrad Nyaláb v Korolevu}

Abstrakt: Hrad Nyaláb, nacházející se v pobliž obce Korolevo Vinogradovského regionu Zakarpatské oblasti Ukrajiny, se vyznačuje silným kulturním souvrstvím, složitou stratigrafii a velkým množstvím vlastního materiálu. Ve výzkumných sezónách v letech 2007, 2011-2014 zde expedice Užhorodské národní univerzity přezkoumala tři obytné mistnosti, objevila konstrukce čtyř kachlových kamen a našla tisice fragmentů keramického nádobí, kachlů a výrobků z kůže, kostí, skla a kovu. Sumární datace kolekce nálezů-konec 13. - polovina 17. století.

Klíčová slova: Korolevo - hrad Nyaláb-kachlová kamna-keramika-kachle.

Within the last decade a significant increase in the number of field archaeological studies of medieval and early modern age sites has been evident in the Zakarpats'ka oblast of Ukraine. The scientists' main attention was focused on the study of the castle of Nevyts'ke (Regional Station of Young Tourists, led by Oleksandr Dzembas) and fortified points in Vynohradiv, Serednye, Bron'ka, Kvasovo, Siltse, Vyshkovo, and Chynadievo (medieval studies expedition of Uzhhorod National University, led by Igor Prokhnenko).

The castle of Nyaláb, located on the north-western outskirts of the village of Korolevo of the Vynohradiv district, stands out through its stratigraphic diversity, rich cultural layer and numerous finds. The castle's mountain of volcanic origin is $52 \mathrm{~m}$ high. It is a kind of a geological mystery because the closest hills are located relatively far from it. The valley of the river Tisza which flows $300 \mathrm{~m}$ from the mountain can be viewed from the top. The square of the central part of the castle is $52 \times 47 \mathrm{~m}$ and is trapezoid in shape. It is located in the north-western part of the upper platform of the mountain. An additional fortified line with a rectangular building (Fig. 1) is located $30 \mathrm{~m}$ from the main castle construction. A wedge-shaped bastion was constructed away from the main architectural complex, on the south-eastern edge of a wing. Its size is $10.15 \times 9.65 \mathrm{~m}$.

The history of the castle is well recorded in scientific literature. However, there are only few publications of actual facts proven by data from written sources. It is especially true about the early periods of Nyaláb functioning which are represented by rare mentions in medieval documents (Komáromy 2001, 16-42). It is known for certain that the area of Korolevo was a favorite hunting place of the "junior king" (junior rex Hungariae) István V (1270-1272). He hunted bison, bears and boars there. It was him who ordered to build a hunting lodge (Domus regalis) on the hill close to Felszász (the former name of Korolevo) in 1262. The early period of the building is mentioned in a letter of Pope Urban IV from 1264. He urged István V to return the hunting lodge to his mother (Maria Laskarina, the Princess of Nicaea) because it had previously been the queen's property.

Stone fortifications had been raised at the end of the 13th century and Nyaláb turned into a castle. After that and until the beginning of the 15th century its owners frequently changed. During the reign of László IV (1272-1290) the castle belonged to the Ubulfi family. Magnate Borsa Beke owned it at the beginning of the 14th century. The property passed into the hands 


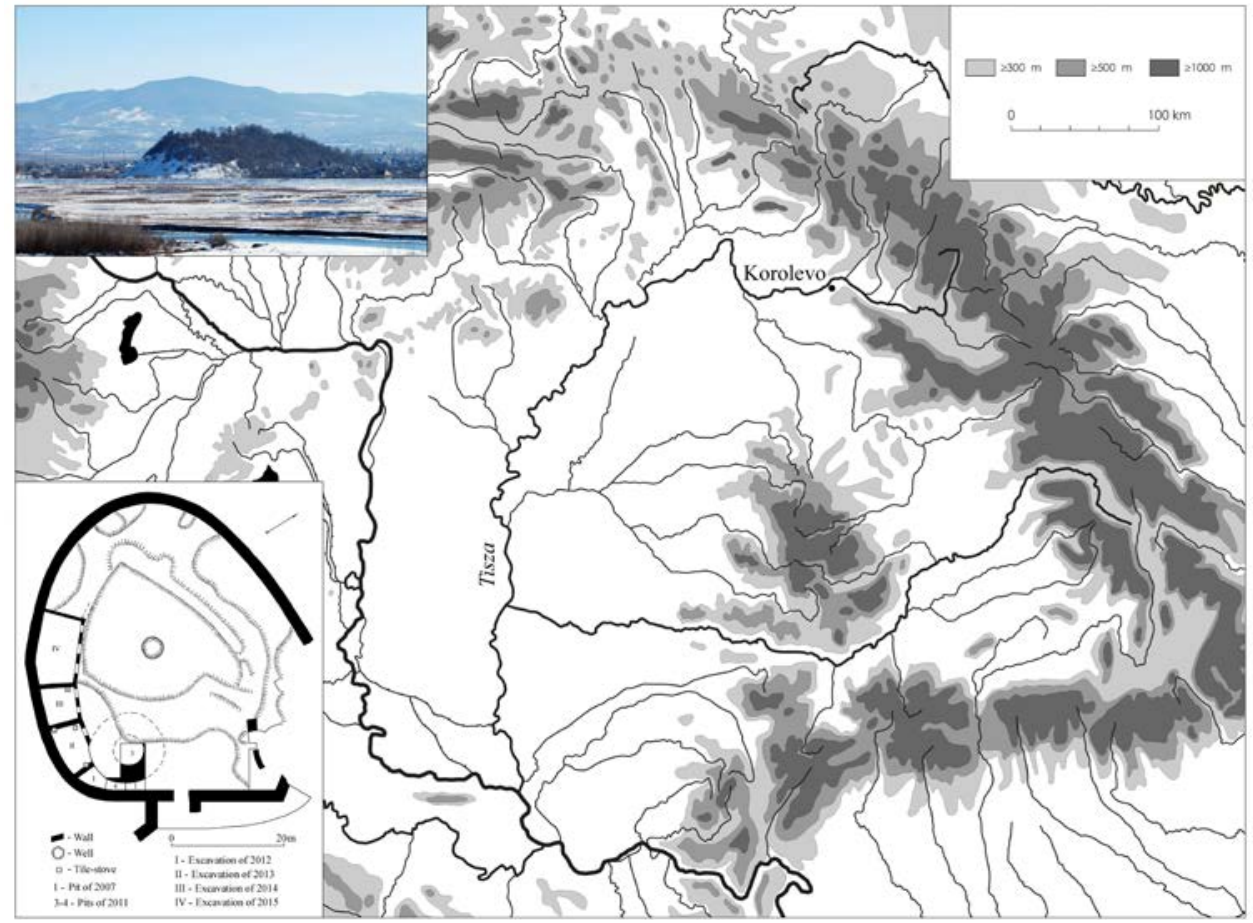

Fig. 1. Korolevo castle of Nyaláb on the map of the Carpathian-Danube area.

Obr. 1. Hrad Nyaláb v Korolevu na mapě karpatsko-dunajské oblasti.

of the Count of Bereg Tamás after the revolt of Csák Máté (1312) against Hungarian King Charles Robert of Anjou (1301/1310-1342). He was ordered by the king to rebuild fortifications which had been ruined during the seige of the castle by the royal army.

Later on the restored castle became the center of a dominium. King Louis the Great (1342-1382) transferred it to the sons of Moldavian Voivode Balk and Drág as a fief ownership in 1378. This was the period of Vlach colonization which had been initiated earlier by Béla IV (1235-1270) after a Mongolian invasion. Under the rule of Drág's descendants the castle performed not only a protective function but was also a cultural center. The Tetra-Gospel in the Slavic language which was rewritten here in 1401 testifies to this (Микитась-Чучка 1968, 62-64).

King Sigismund (1387-1437) deprived Drág's family of their property after the 1403 revolt and passed it to Perényi Péter in 1405. Apart from a short period of time in the second half of the 15th century when the castle belonged to Báthori, Nyaláb remained in the hands of the Perényi family.

The barons took care not only of the reinforcing of the walls but also of the interior of the castle. They were famous for their patronage. Frangepán Katalin, the widow of Perényi Gábor deceased at Mohács in 1526, financially supported the publication of "The Letters of Saint Paul in the Hungarian Language" (Az zenth Paal leueley magyar nyeluen). The book was translated from Latin in Nyaláb by Komjáti Benedek and published in Krakow by Hieronymus Vietor's printing workshop in 1533. The "Letters" with the translator's notes became the first printed book in Hungarian (Székely 1957, 19).

Szilágyi (Ilosvai 1886) argued that the famous poet of the 16th century Ilosvai Selymes Péter had written a poem about Toldi Miklós in the Korolevo castle. Later it became a basis for Arany János trilogy (Az híresneves Tholdi Miklósnak jeles cselekedeteiröl és bajnokságáról való história). Balassy Bálint, a prominent Hungarian protagonist of renaissance lyrics, also visited Nyaláb. 
The final stage of the castle's history is connected with events which followed the Wesselenyi Ferenc revolt in the 1660s. Several noble families from the Ugocsa County were actively involved in it. Emperor Leopold I (1655-1687) lost his trust in nobility of northeastern Hungary. He sent a garrison under the command of Meyer Konrád of Brandenburg to Korolevo and ordered to destroy the fortifications. Perényi tried to save the castle and delegated the Count's deputy Hartányi János to the Emperor but his efforts failed. The walls of Nyaláb were demolished at the end of 1671 - the beginning of 1672 and were not restored again.

In spite of the complex history of the castle, only irregular and minor archeological studies took place on the site and its surroundings in the past. In particular, in the 19th century the Hungarian National Museum (Budapest) received finds from Korolevo (in 1859 and 1881). These were different pieces of jewellery, including a gilded copper ring and a branch with flowers made of precious stones, and a double Lorraine type copper cross. Three coffin nails with star-shaped heads covered in silver foil were among the finds as well. Obviously, these items originated from the chapel crypt where wealthy people were buried.

In a hundred years, in the $1980 \mathrm{~s}$, minor research was undertaken close to the central part of the fortifications by the Palaeolithic expedition of the Museum of Nature (Kiev). Researchers collected late medieval finds including a fragment of a Hungarian coin of King Matthias Corvinus.

The expedition of the Ukrainian Specialized Scientific and Reconstruction Institute "Ukrzahidproektrestavratsia" excavated more than twenty test pits in the area at the beginning of the 1990s (Пам'ятки... 1993). However, these can be only nominally considered archaeological. The study was not about stratigraphy and the cultural layer of the castle but interior planning of the construction. It stopped at the level of $0.5 \mathrm{~m}$ (the real depth of the cultural level here is $4-5 \mathrm{~m}$ ).

In 2007 expeditions of Uzhhorod National University started studying the Korolevo castle of Nyalab. During 2007, 2011-2014 five test pits and three excavation sites were set up in different parts of the monument in the area of $140 \mathrm{sq}$. $\mathrm{m}$. The depth of the cultural layer varied from 1.5 to $5.7 \mathrm{~m}$. Three residential rooms with tile-stoves were explored and a significant collection of materials was found during the work, in particular: thousands of fragments of ceramic utensils, including imported ones, stove-tiles, leather, bones, glass and metal products (household items, craftsmen's tools, fragments of clothing, decorations, medallion, tokens, textile seals, coins and weapons; Прохненко 2007, 105-110; 2008, 186-188; 2009, 205-208; 2013, 32-39; ПрохненкоГомоляк 2007, 83-94; 2009, 71-97; 2013, 170-171; 2013a, 171-172; Прохненко-ГомолякМойжес 2007, 219-255; 2009, 296-301; 2011, 187-234; 2011a, 213-232; Прохненко-МойжесГомоляк 2012, 59-78; Прохненко-Мойжес-Жиленко 2012, 204-248; 2013, 142-151; 2013а, 152-163; Пьянчак-Прохненко 2008, 166-177; Prohnenko-Mojzsesz-Zsilenko 2012, 241-285; 2013, 203-250; Mihok-Prochnenko 2008, 149-165).

Ceramic utensils make up the largest collection from the castle. The assortment is mainly represented by wheel-turned pots, vessels, "frying pans" and cups of local origin.

The pots are made of well elutriated clay with an admixture of fine-grained sand. They are well fired and vary from light grey to dark brown in colour. The vessels have an oval body and thick rims. The parameters of the reconstructed items are as follows: rim diameter $11.4-23.5 \mathrm{~cm}$, foot diameter $-5.7-11.0 \mathrm{~cm}$, height $-15.2-30.2 \mathrm{~cm}$ (Figs. 2:1-4).

A separate group of vessels consists of grey clay pots with a rim and a shoulder attached handle. Their necks are ornamented either with embedded horizontal lines or roller-shaped decoration with notching. The parameters of the two reconstructed items are as follows: rim diameter -17.8 and $19.4 \mathrm{~cm}$, foot diameter -9.0 and $10.8 \mathrm{~cm}$, height -21.5 and $25.3 \mathrm{~cm}$ (Figs. 2:8-9). Such pots are characteristic of the complexes in the Upper Tisza region of the first half of the 17th century (Uličný 2004).

The vessels are made of thoroughly prepared clay and fired through. The ochre surface of one of them is covered in red painting. The parameters of the two reconstructed vessels are as follows: rim diameter -3.2 and $6.7 \mathrm{~cm}$, foot diameter -8.5 and $10.0 \mathrm{~cm}$, height -25.7 and $23.0 \mathrm{~cm}$ (Figs. 2:10-11). The vessels also belong to regional utensils from the first half of the 17 th century (Uličný 2004). 

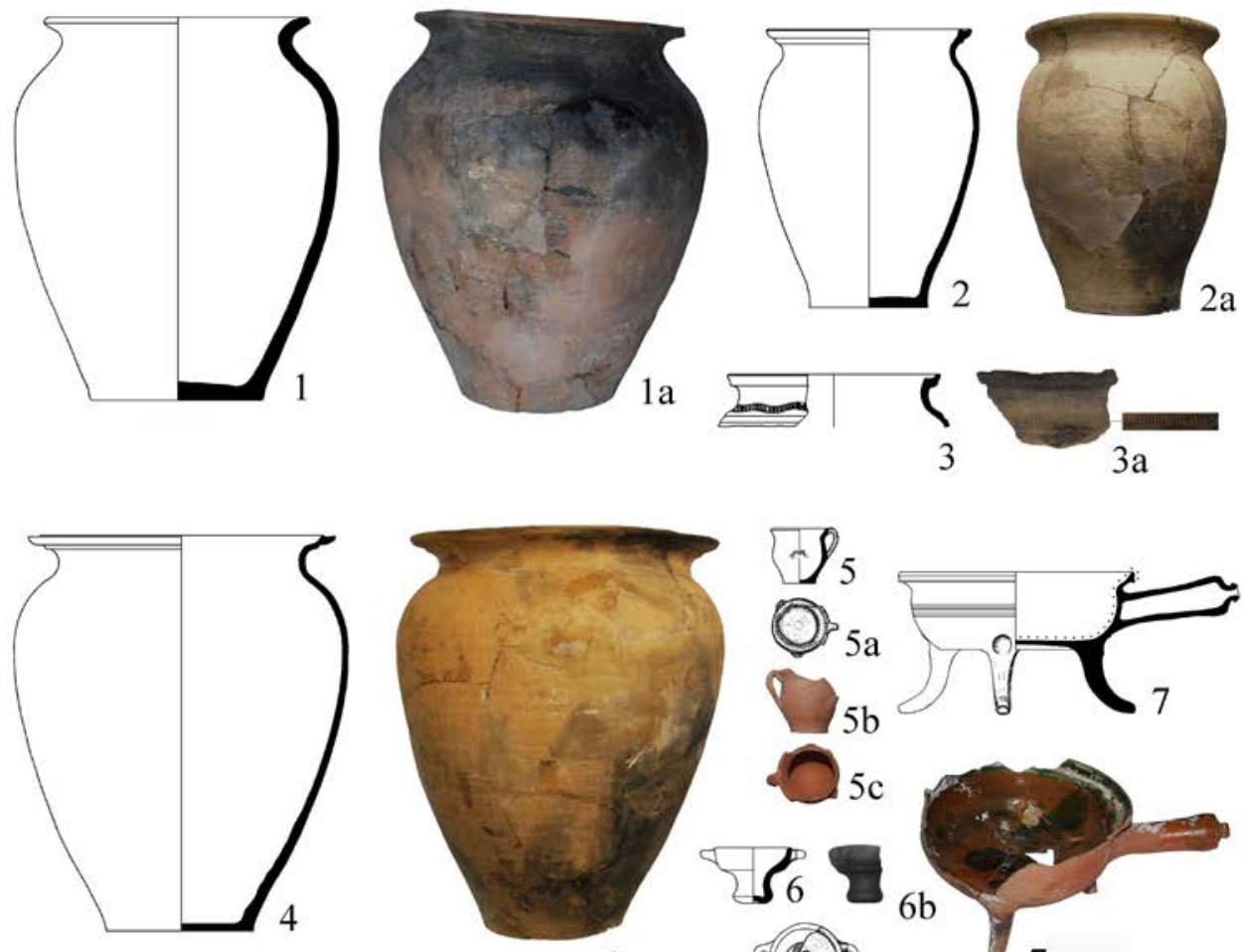

$4 \mathrm{a}$
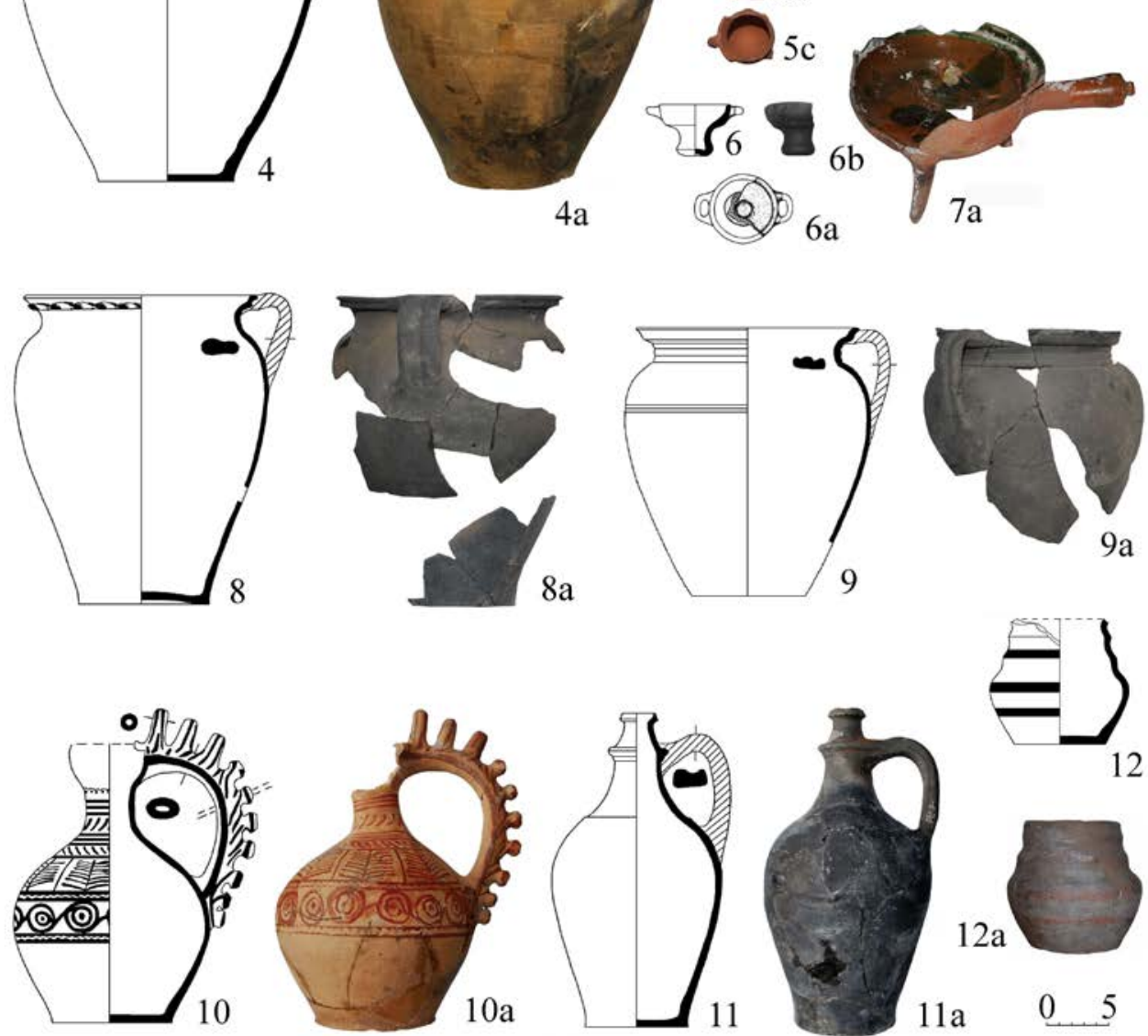

Fig. 2. Korolevo - the castle of Nyaláb. Ceramic utensils.

Obr. 2. Korolevo - hrad Nyaláb. Stolní a kuchyňská keramika. 
The "frying pans" are represented by a bowl with a handle and three tall legs curved on the outer side. They are made of well elutriated clay. Brown items are well fired. They are covered in green or brown glaze inside but sometimes on the outside, too. The rims of the "frying pans" are thick and have $8.5-16.5 \mathrm{~cm}$ in diameter. The depth of a reconstructed bowl is $3.0-7.0 \mathrm{~cm}$, height of the legs is $3.2-4.6 \mathrm{~cm}$ (Fig. 2:7). Such ceramics were widespread on the archaeological sites of the Upper Tisza region at the turn of the 16th and 17th century (Uličný 2004).

Cups are made of thoroughly prepared clay with a small admixture of fine-grained sand. They are well fired and are beige in colour. The cups are conical in shape. Their surface is covered in embedded horizontal lines. The rims are horizontally truncated and have $14.8-15.7 \mathrm{~cm}$ in diameter. Similar cups are known from most sites of the region in layers from the 16th century.

Two miniature shapes differ from the others: an ochre pot with three handles (height $3.6 \mathrm{~cm}$; Fig. 2:5) and a two-handle grey cup (height $-4.1 \mathrm{~cm}$; Fig. 2:6).

It is worth mentioning the significant domination of the 16th and 17th centuries utensils at the castle of Nyaláb and a small number of earlier ceramics. The ceramics from the end of the 13th and 14th centuries are the most plentifully represented in the fill of a pit in subsoil oval in shape $(2.2 \times 2.4 \mathrm{~m})$, pit 1 (depth $-1 \mathrm{~m})$. It was defined as a midden. Fragments of a slender pot related to the utensils were collected in the southern upper humus layer of pit 1 . The pot has well cambered but slightly shaped rim. It has a wide neck, a high distinct shoulder, and an onion-shaped body. The thickness of its walls stands at $0.9 \mathrm{~cm}$; the pot is made of well elutriated clay with a small admixture of sand and fine-grained stones. A brown vessel was fired at a high temperature. Its parameters are as follows: rim diameter $-19.8 \mathrm{~cm}$; foot diameter $-12.8 \mathrm{~cm}$; height $-28.7 \mathrm{~cm}$ (Fig. 2:1). Despite the wide dissemination of similar pots within this significant period of time, the features of its form and morphology of clay make this vessel different both from ceramics of Rus and from the typical utensils of the 15th and 16th centuries. This suggests that it can be dated to the end of the 13th or to the 14th century.

A small pot which was discovered in the lower horizon of pit $1 \mathrm{can}$ be defined as a rare one. It has a conical body, a distinctive shoulder, and a high wavy neck. The rim was broken off. The pot's surface is decorated with painting - three horizontal red lines. This item is made of loose but well elutriated clay with a significant admixture of sand. A brown vessel was fired at a high temperature. It parameters are as follows: rim diameter $-7.3 \mathrm{~cm}$; foot diameter $-7.1 \mathrm{~cm}$; height of preserved part $-9.7 \mathrm{~cm}$ (Fig. 2:12).

Medieval painted ceramics had been known in Bohemia and Moravia since the second half of the 13th century but became mass products in the 14th and 15th centuries. This pot represents flask-shaped vessels and can be dated to the end of the 13th or to the 14th century.

Fragments of other pots found in the fill of pit 1 belong with the vessels with usually slightly cambered rims (diameter - 11.7-20.2 cm) and oval in shape. The items are made of well elutriated clay with a significant admixture of sand. The fired fragments vary in colour, from beige to dark brown. Most of them have the features of earlier medieval ceramics, which is primarily visible in the strongly cambered and slightly shaped rims or the presence of a small gutter from the inside. It is worth mentioning ornamentation of upper parts of the vessels with different combinations of wavy and straight horizontal lines. A fragment of a vessel's foot with a brand representing a cross inside a square was also found among the ceramics of pit 1.

Imported utensils are represented by the fragments of four items at the castle of Nyaláb. The first one is a brown glazed jug. Its upper part is decorated with zoomorphic (dragons) and geometric (straight convex strips covered with embedded wavy lines) images. The jug's reconstruction suggests that it was slim in proportions with a tall, straight and wide-open neck. There is a groove and a ribbon inside the rim which is typical of medieval ceramics. Several rows of horizontal impressions decorate the neck from the outside. The body is oval-shaped with the widest expansion in the central part. A high handle is attached to the rim and the body. Parameters of the vessel are as follows: rim diameter $-11.9 \mathrm{~cm}$; foot $-8.3 \mathrm{~cm}$; height $-24.7 \mathrm{~cm}$ (Fig. $3: 1$ ). Considering its general shape, the rim shape, the features of clay and the glaze, it can be dated to the end of the 14 th - beginning of the 15 th centuries. 

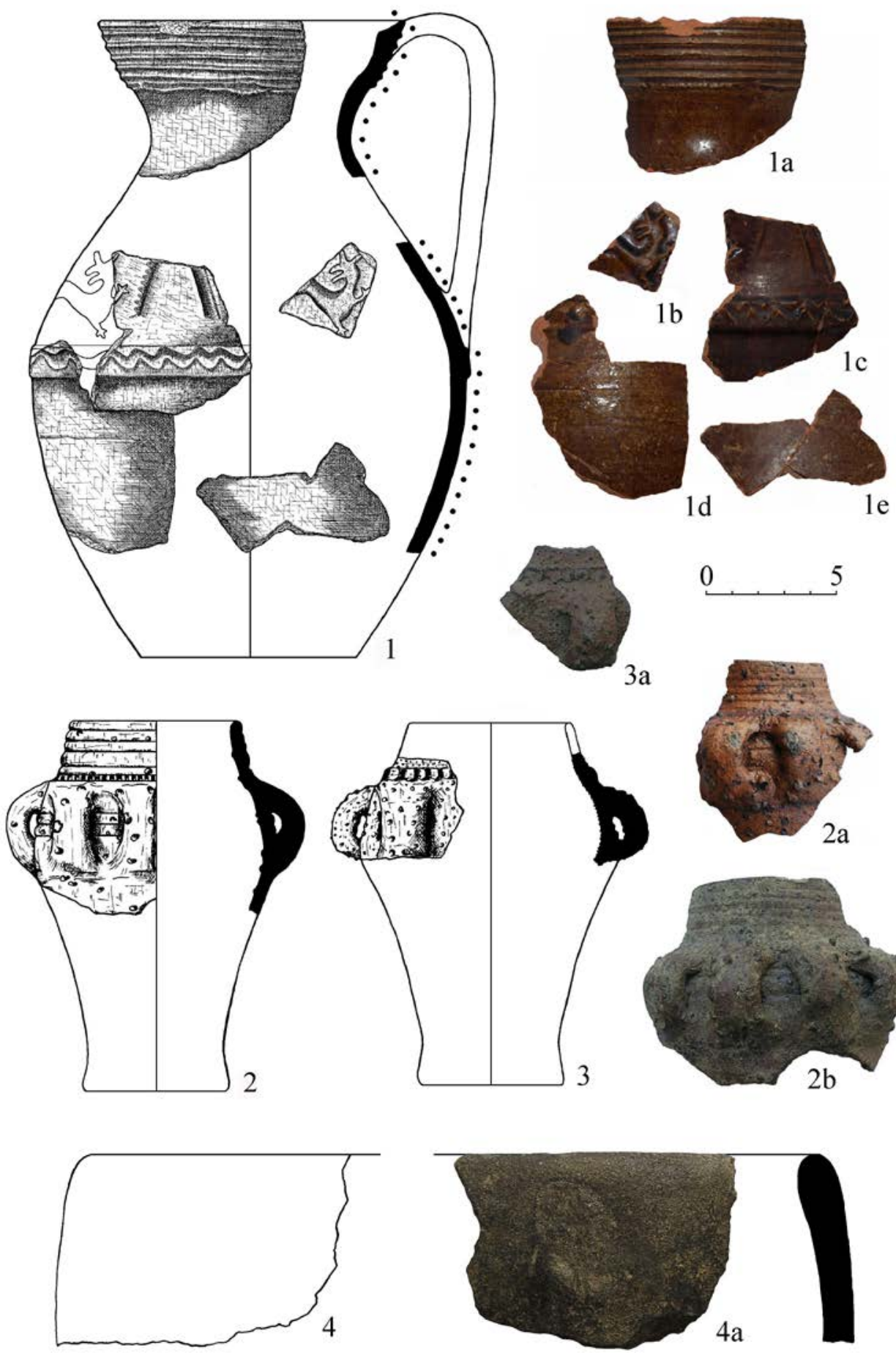

Fig. 3. Korolevo - the castle of Nyaláb. Imported vessels.

Obr. 3. Korolevo - hrad Nyaláb. Importované nádoby. 
Two cups from the Korolevo castle are of Moravian origin. The first one has a straight tall rim (diameter $-6.7 \mathrm{~cm}$ ), decorated with five furrow-stitches. Ten vertical decorative ear-shaped handles are attached to the vessel's shoulder. Above them it is decorated with horizontal rows of notches. Elutriated clay was well fired (resonant). The maroon surface is evenly covered with vesicles - "warts" (Fig. 3:2). Another cup is similar in shape and texture. It is represented by a side part with one intact and one damaged ear-shaped handle. A horizontal row of small tweaks is located above the handles (Fig. 3:3).

This high quality utensil holds a special place among medieval ceramic complexes of Europe (Drobná 1957, 98-107). It is distinguished by the composition of clay. It was made with significant iron admixtures that turn into empty bubbles at high temperatures. According to the finds' mapping, Moravian cups were produced in Loštice (near Olomouc; Goš 2007; NekudaReichertová 1968, 150, obr. 48) or in the surrounding area (Polla 1986, 232). V. Goš and J. Novák defined this territory as a northern Moravia production area (Goš-Novák 1976, 399-404). Loštice pottery was produced from the 14th until the 16th centuries (Nekuda-Reichertová 1968, 151; Goš-Novák 1976, 399-404; Goš 2007).

Only few single finds of similar texture have been unearthed in the Upper Tisza region. All of them originated from the western part of the region (Krásna nad Hornádom, Šariš, Bardejov; Čaplovič-Slivka 1985, 49, Figs. 1:1, 4, 10, 40; 75, Tab. XXXI: 5-6, 8-9; Polla 1986, 230, 232). New data from the Korolevo castle of Nyaláb supports the revision of the borders of the Loštice pottery area. These finds, as well as new data from Romania (Bencze 2008) and Transcarpathia (Uzhhorod-Goryany; Мойжес 2014, 133), extends the area to $160 \mathrm{~km}$ in the eastern direction.

A fragment of a rim made of clay with a significant graphite admixture also belongs to imported items (Fig. 3:4). Medieval graphite ceramics is well represented in the complexes in the territory of Austria, the Czech Republic and North-western Slovakia. In Eastern Slovakia it is known as rare fragmentary finds. However, it was never found in Transcarpathia before the excavations at the castles of Korolevo and Bron'ka (Прохненко-Гомоляк-Мойжес 2008, 139-148). According to scientific literature, these items are classified as crucibles and Austria is considered the center of their production (Scharrer-Liška 2007, 62-65; Keramische, 84-85).

A collection of stove-tiles comprises one of the best represented categories of the Korolevo castle's inventory. They were mainly found in the fill of the cultural layer in the whole area of the monument. The variety of types, forms, moulds and production technologies of Korolevo stove-tiles suggests that a significant number of tile-stoves functioned at the castle of Nyaláb. Currently, the constructions of four of them are studied. They are represented by foundation platforms and smoke removal elements made of stone and brick. Complete tiling is evident in one case only (tile-stove 4). A pile of stove-tiles in a firebox of tile-stove 1 cannot be directly related to this masonry heater. More likely, the tiles originated from several destroyed heaters. The stove-tiles are completely absent in the cases of tile-stoves 2 and 3.

Tile-stove 1. It is dated to beginning of the 16th century. Its stove-tile layout was disassembled in the 17th century and stored in its firebox made of tuff blocks. The firebox was oval in shape, framed with three rows of half brick masonry. The masonry was slightly tilted inside the construction in the upper part. An arched ceiling made of relatively light tuff blocks was built $2.5 \mathrm{~m}$ above the firebox. The firebox mouth led to the wall chimney. Two residential rooms 1a and $1 \mathrm{~b}$, one above the other, were located behind it. The stove design features suggest that it was a hybrid of tile-stoves and stone-ovens of the hypocaustum type (Figs. 4:1-1a).

Tile-stove 2. It was located in the south-western corner of room $1 \mathrm{~b}$. It was built at the end of the 15th - beginning of the 16th centuries and disassembled during the redevelopment of the castle walls in the 16th century. As a result, only a built-in wall stove's firebox has survived. It was covered with stones, partially filled with mortar, and closed by ceiling tuff blocks of room 1a. Preserved part of the firebox is crowned with an arch and well fired bricks on the sides. There is a small square chimney $(0.1 \times 0.1 \mathrm{~m})$ on the wall $20.0 \mathrm{~cm}$ above the arch (Figs. 4:2-2a). 

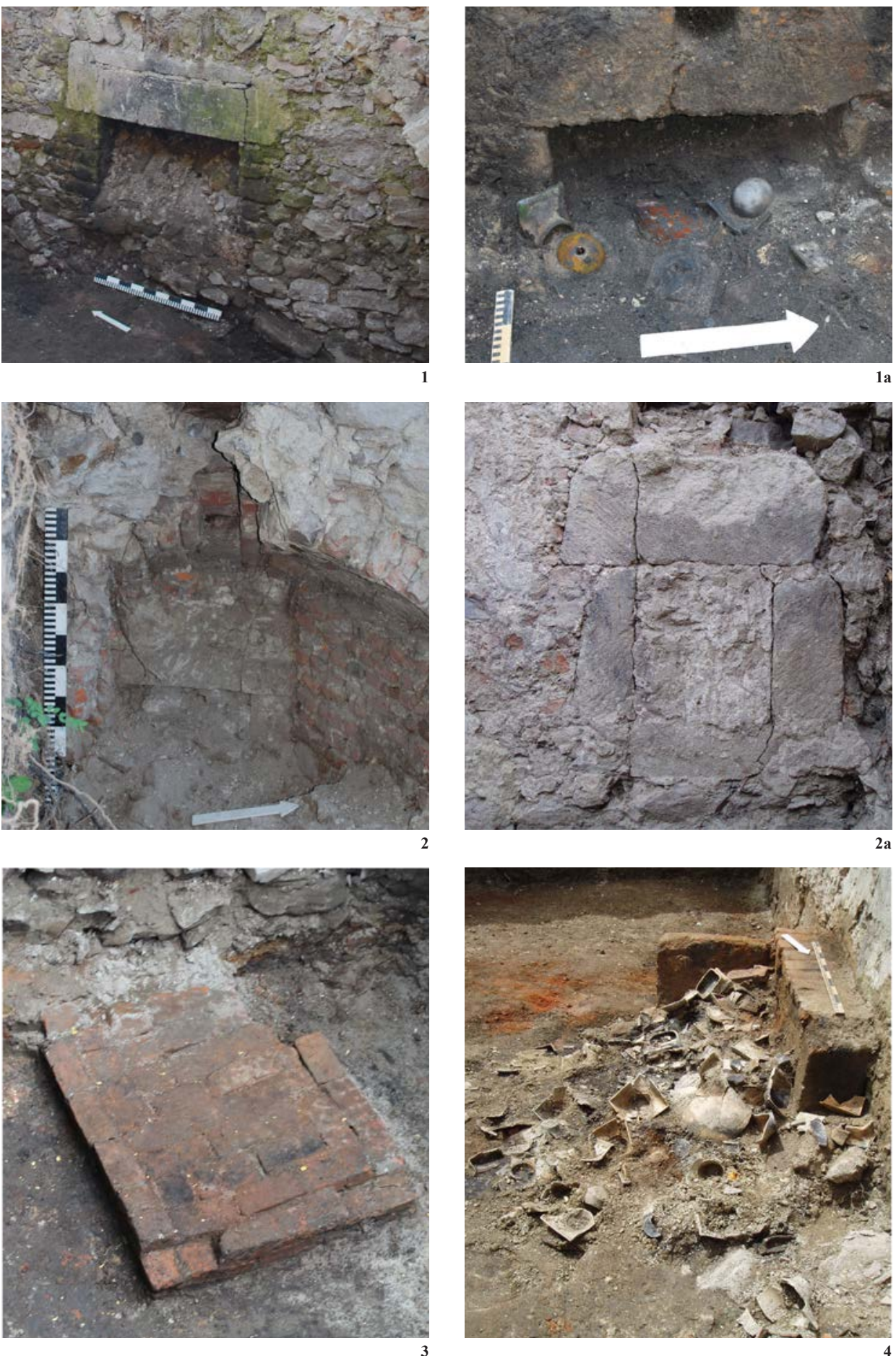

Fig. 4. Korolevo - the castle of Nyaláb. The remains of tile-stove frames. Obr. 4. Korolevo - hrad Nyaláb. Zbytky konstrukcí kachlových kamen. 
Tile-stove 3 . It functioned in the first half of the 17 th century. Approximately square platform $(1.1 \times 1.2 \mathrm{~m})$ made of two layers of bricks and covered with a thin layer of daub has survived in the north-western corner of room 1a (Fig. 4:3).

Tile-stove 4. Its remains are located at the western wall of room 2, $0.6 \mathrm{~m}$ from the entrance. The stove's base (size $-1.6 \times 1.3 \mathrm{~m}$ ) is made of small tuff blocks at the floor level. Two stone slabs, joined by iron brackets, were installed vertically on the tuff basis. This was a substructure for the lower part of the stove which also included more than 60 pot-shaped tiles. The upper part of the stove was assembled from unglazed panels with floral ornamentation and green glazed panels with both floral and zoomorphic (unicorns, bird-dragon) images (Figs. 7:1-2). The upper framing of the tile-stove consisted of green glazed crest tiles crowned with harp-like merlons (Fig. 12:3). Firewood was loaded in the stove from the room. Smoke was removed through a massive ceramic chimney (height $-0.86 \mathrm{~m}$; lower vent diameter $-0.48 \mathrm{~m}$; upper vent diameter $0.3 \mathrm{~m}$ ) decorated with wavy and horizontal lines. As already mentioned, the year of construction was defined by the date on the tile with unicorns -1610 .

A collection of stove-tiles that are not directly related to a particular tile-stove consists of different types of tiles: pot-shaped, onion-shaped, panel, and hybrid tiles with floral and zoomorphic décor, anthropomorphic and zoomorphic images, religious themes, heraldic symbols, as well as crest tiles from the upper framing of a tile-stove, etc. The finds were made of well elutriated clay with an admixture of sand. They are well fired (mainly resonant). The stove-tiles are ochre to light grey and dark brown in colour.

Several dozens of panel tiles were reconstructed. Besides few exceptions, they were not decorated with glaze. All have a horizontally truncated external flange and are square in shape. Their size is $18.5-22.1 \times 19.1-21.9 \mathrm{~cm}$. The bottom is round in shape, $7.5-10.0 \mathrm{~cm}$ in diameter (Figs. 5:1-2).

The next type is represented by onion-shaped tiles. They look like large inverted glasses without a base. Most of them are covered with green glaze. Their parameters are as follows: 17.0-24.6 cm high; diameter of the base - 10.5-12.2 cm (Figs. 5:7-8).

Hybrid stove-tiles are a kind of combination of pot-shaped and onion-shaped finds. Their front side is covered with green or yellow glaze. Many are moulded with roller-shaped decoration with notching and embedded horizontal and vertical lines. All items have a horizontally truncated external flange and are square in shape. Their size is $18.8-22.0 \times 19.7-22.0 \mathrm{~cm}$. The bottom is round in shape. Two items have cutouts in the bottom (Figs. 5:3-6).

A significant number of panel tiles was found too. The items covered with floral ornament comprise a separate group among them. They are characterized by uniformity and the diversity of décor. Usually a flower or a cross are located in the center of a tile. The flowers or leaves spread from there to the corners but sometimes to the sides of the stove-tile. In one case, only a flower (lily) is placed in a vase in a still life style (Fig. 6:6). Most tiles are glazed in green, light green, and brown. Unglazed examples are also present. The external surface is usually approximately round in shape of the following size: $19.7-21.3 \times 19.8-21.5 \mathrm{~cm}$, depth $-7.6-8.8 \mathrm{~cm}$ (Figs. 6:1-5).

Zoomorphic images on the stove-tiles of the castle of Korolevo are represented by four moulds. The first one is a set of panel stove-tiles with two unicorns whose heads are turned in opposite directions. The animals are in sitting positions and their bodies are covered with a scale-like décor. Two bent and heart-shape twisted flowers rise above them. Production date can be seen at the top part of the stove-tile. Obviously, tile stove 4 was made at the same time 1610. Except one example, all stove-tiles from this set are covered with light green glaze. Their parameters are: width $-21.0 \mathrm{~cm}$; height $-21.0 \mathrm{~cm}$; depth $-7.0 \mathrm{~cm}$ (Fig. 7:1). It is worth mentioning that the unicorns symbolize purity and virginity in iconography and usually accompany the Virgin Mary (Pavlík-Vitanovský 2008, 539-558).

Green glazed panels comprise the next type of stove-tiles. A fantastic bird with a massive body and straightened wings is depicted on the front side. In general, it resembles a dragon. The creature is covered with scale-like décor similar to the ornamentation of the unicorns. The parameters of the stove-tiles are as follows: width $-20.0 \mathrm{~cm}$; height $-22.0 \mathrm{~cm}$; depth $-7.5 \mathrm{~cm}$ (Fig. 7:2). 

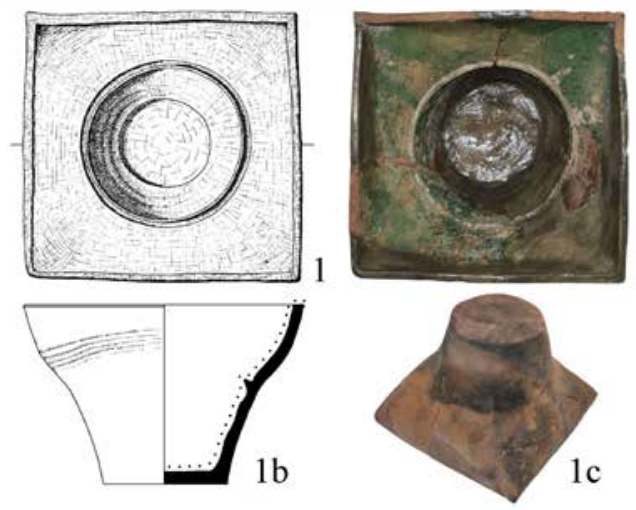

1a
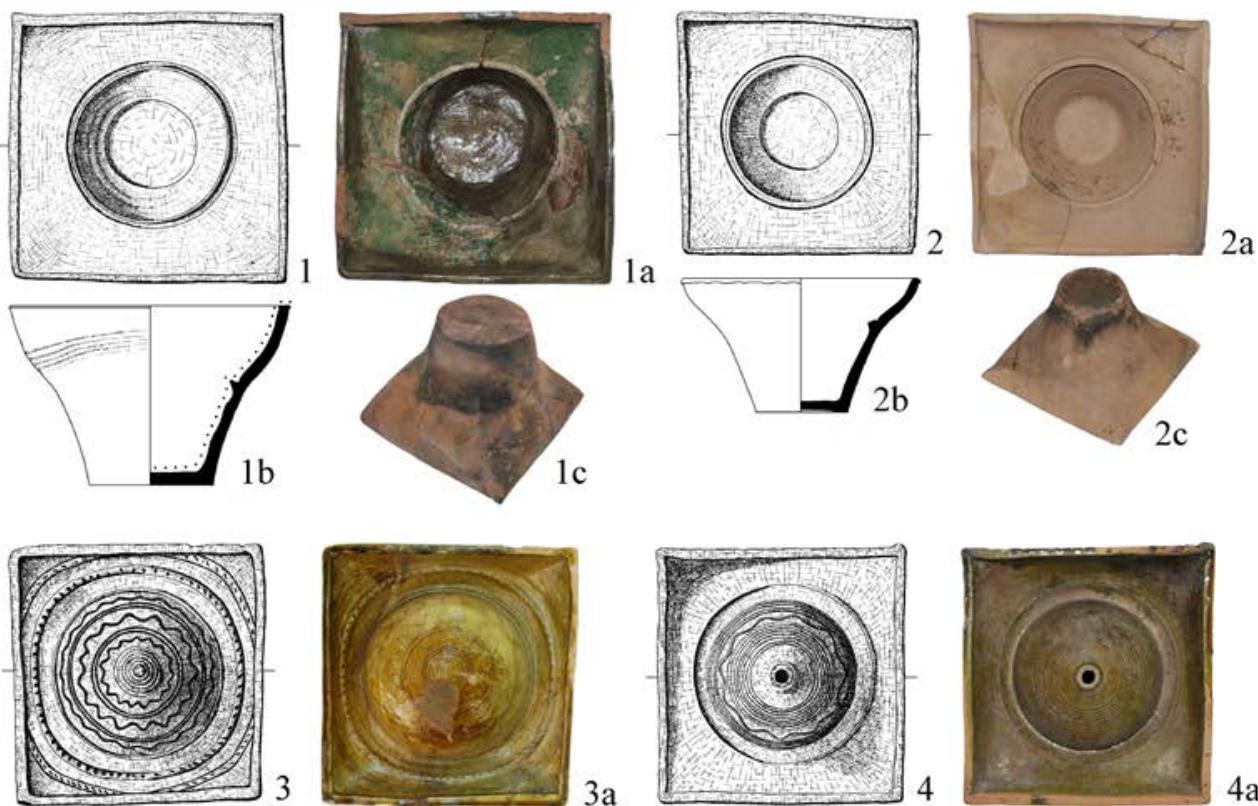

$3 \mathrm{a}$
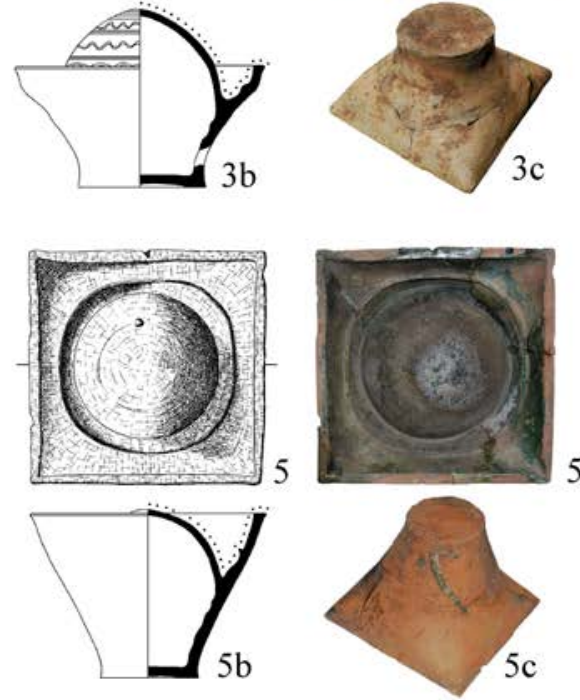

$5 \mathrm{a}$
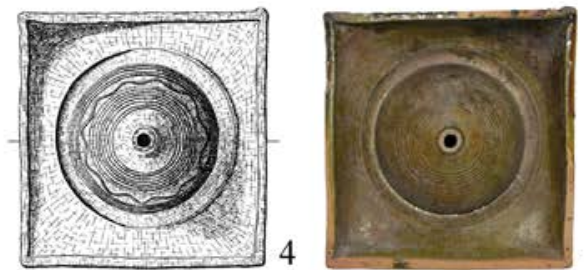

$4 a$
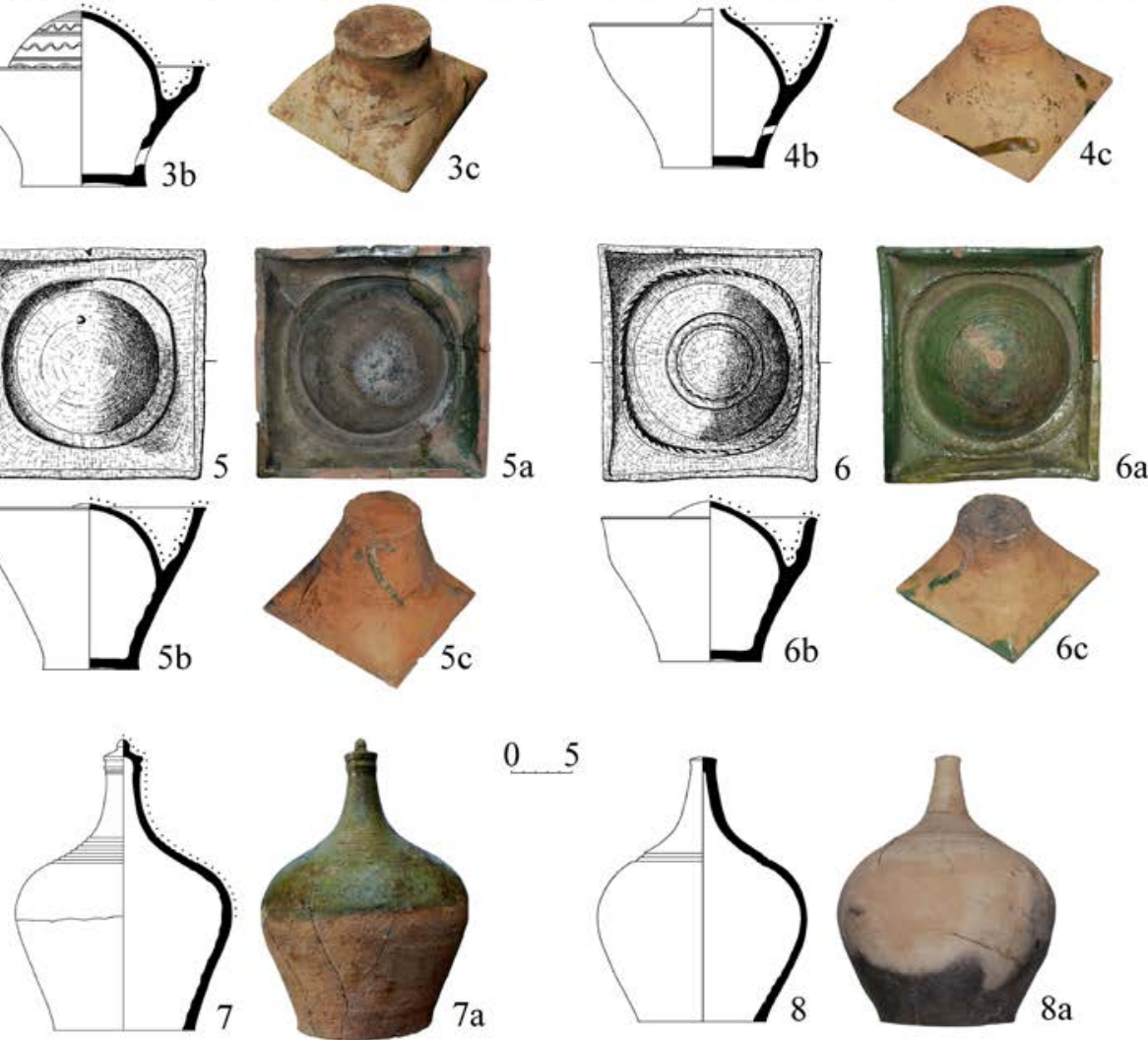

Fig. 5. Korolevo - the castle of Nyaláb. Pot-shaped and onion-shaped stove-tiles.

Obr. 5. Korolevo - hrad Nyaláb. Miskovité a baňkovité kachle se zašpičatělou hlavicí. 

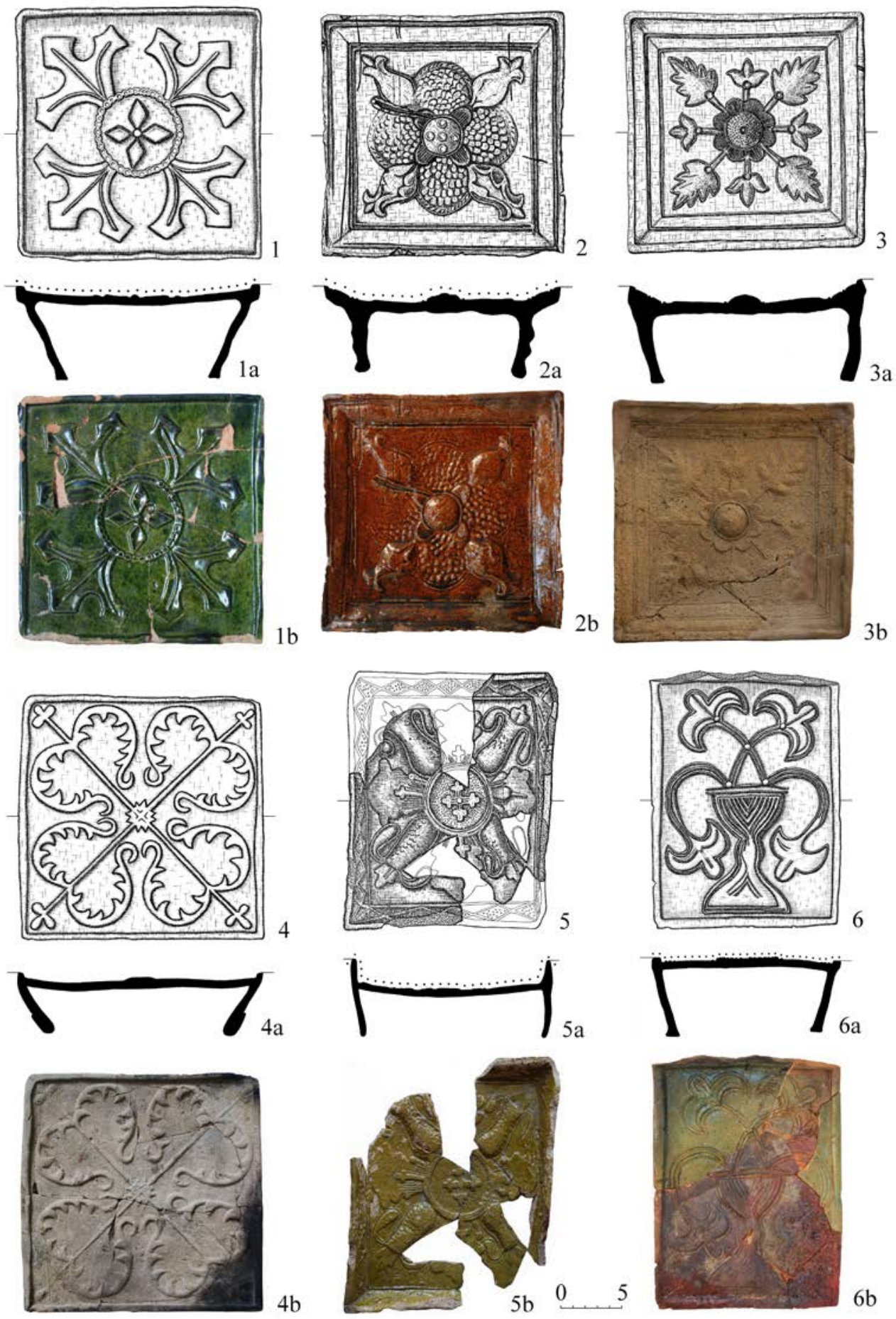

$6 \mathrm{~b}$

Fig. 6. Korolevo - the castle of Nyaláb. Panel tiles with floral ornament.

Obr. 6. Korolevo - hrad Nyaláb. Komorové kachle s květinovým ornamentem. 

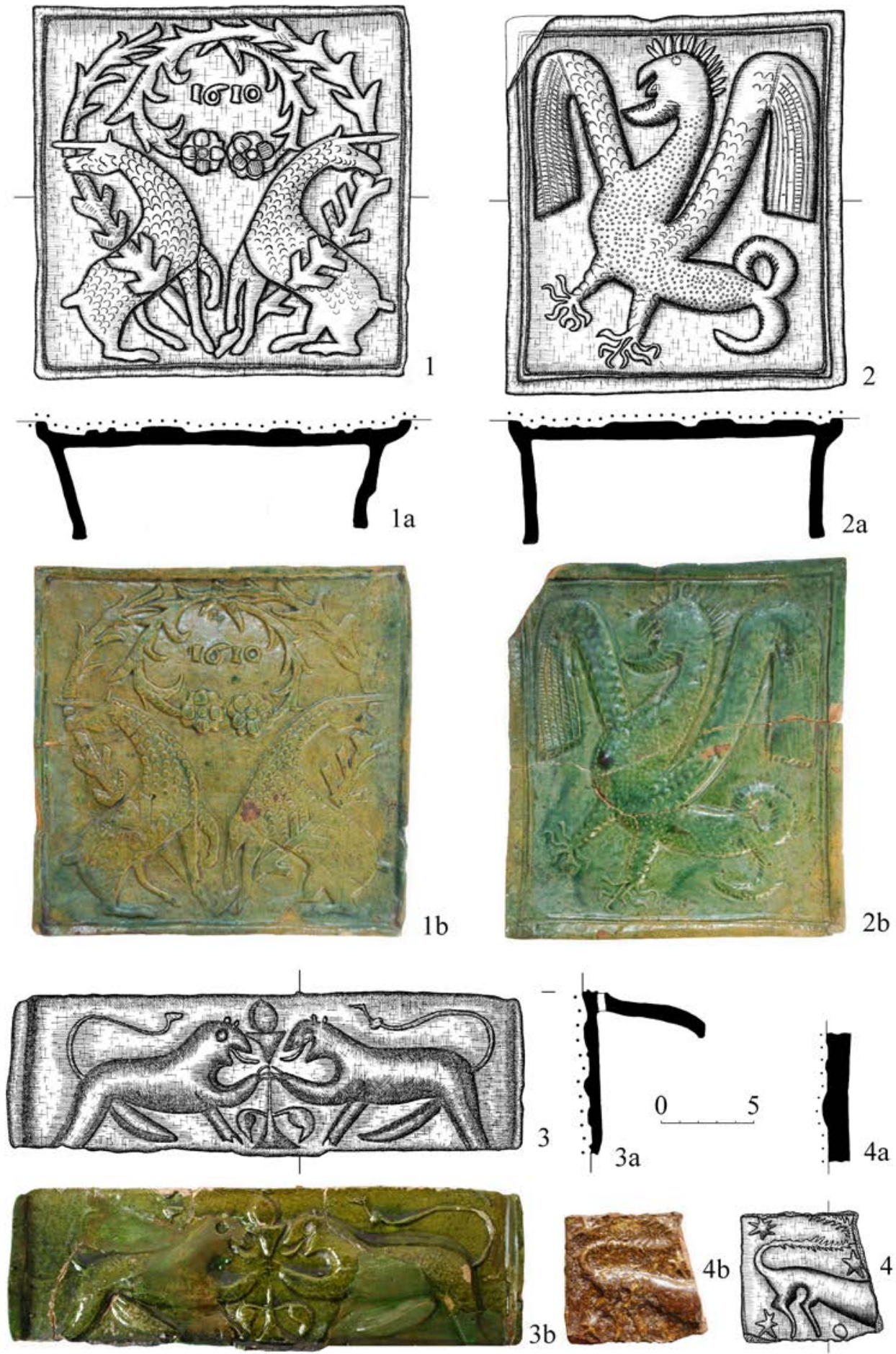

Fig. 7. Korolevo - the castle of Nyaláb. Panel tiles with the images of animals. Obr. 7. Korolevo - hrad Nyaláb. Komorové kachle se zoomorfními motivy. 
A separate set of stove-tiles consists of green glazed panel items with the image of two leopards. The animals walk to meet each other and support a flower with their paws. The parameters are: width $-27.9 \mathrm{~cm}$; height of preserved part $-9.1 \mathrm{~cm}$ (Fig. 7:3).

A stove-tile fragment $(5.3 \times 5.1 \mathrm{~cm})$ covered with yellow glaze was found near stove 3 . It shows a part of a stylized lion with a long curved tail. Three stars are next to the animal (Fig. 7:4).

Usually, stove-tiles with anthropomorphic images comprise a significant group on sites from the late Middle Ages. The best preserved stove-tile was found in the firebox of stove 1 . This is a panel stove-tile with a yellow-glazed front side. A mounted knight is depicted on it. He is armed with a sword, a spear, a shield and a helmet. The external surface of the stove-tile is rectangular $-17.6 \times 20.4 \mathrm{~cm}$. The depth is $5.4 \mathrm{~cm}$ (Fig. 8:1). Similar stove-tiles are known from sites in Romania (Istrate 2004, 115-140; Pl. 3; 14; 15).

Only one stove-tile with a secular motif was found in Korolevo. This is a fragment of a panel tile covered with light brown, green and black polychrome glaze. Analogies from Trebišov and Košice (Slovakia; Chovanec 2005, 54; Rusnák 2014, 348; Tab. XIII, 3) suggest that its surface was approximately square in shape $(21.0 \times 22.8 \mathrm{~cm}$; Fig. 8:2) and depicted a betrothal scene. Visual comparison of the stove-tiles indicates that a mould, made in a Košice workshop, was brought to nearby (Trebišov) and distant (Korolevo) sites. The stove-tiles were made of local clay using this mould and painted according to the colour scheme of particular stoves.

The items depicting Old Testament scenes comprise a separate group among stove-tiles with anthropomorphic images (Прохненко-Мойжес-Жиленко 2013, 142-151; ProhnenkoMojzsesz-Zsilenko 2012, 241-285). The first motif is a king sitting on a throne under an arch. He holds a scepter in the left hand and props up his side with the right hand. Panel stove-tiles are green, mustard or grey glazed. Their front side is approximately square in shape $(23.0 \times 23.2 \mathrm{~cm}$, depth $-5.8 \mathrm{~cm}$; Figs. 9:1-2). Iconography and symbols on similar finds from the region (Košice, Šariš, Füzér; Slivka-Vallašek 1991; Feld 2002, 37-38) suggest that the image relates not to a particular Hungarian king but is a modernized depiction of biblical kings David or Solomon.

Unlike the previous one, the next scene is represented in fragments. These are the remains of a green glazed panel. In spite of their small size, it was established that Samson tearing a lion's mouth is depicted on it (Figs. 9:3-6). There is an analogy for three fragments from one mould, an intact stove-tile from the Museum of Applied Arts (Budapest, Hungary; Gruia 2010, 203-211; $2013,353)$. This was one of the most popular medieval motifs. Gruia counted nineteen different moulds with Samson and a lion in the territory of the Hungarian kingdom (Gruia 2010, 203).

Stories of saints are also presented in the collection of the stove-tiles with anthropomorphic images. Similarly to most European sites, an episode with Saint George fighting a dragon was especially popular at Nyaláb. It is represented by two types of stove-tiles. The first one consists of panel tiles glazed in brown or green. Their exterior is square in shape $-19.5 \times 19.8 \mathrm{~cm}$. George on horseback pierces a dragon with a spear. The saint wears armour and holds his spear underarm in the right hand. The image is not realistic at all. The artist paid a special attention to the face which is disproportionally large to the size of the entire body. A kneeling praying princess begging for salvation is depicted in the upper right corner close to George's head. A winged dragon lies under the hooves winding his tail around the hind left leg of the horse. George sends the spear to the mouth of the creature (Fig. 10:1).

A significant number of variations of this motif can be found on the stove-tiles of the late Middle Ages and early Modern Age (Gyuricza 1992; Gruia 2006, 7-48; Krása... 2008). A fragment found at the Trebišov castle of Parič (Slovakia) is the only one completely identical to the tile from Korolevo (Chovanec 2005, 54). In spite of the same mould, the find from the residence of Palatine Imre Perényi is much more beautiful and covered with a polychrome painting.

The fragments of three stove-tiles from a different mould depicting Saint George slaying the dragon were also found in Korolevo. These are yellow and green glazed panels with partly preserved images of a princess, St. George, a horse, and a dragon. Almost an intact stove-tile from this mould was found in Târnava (Romania) and is stored in the Museum of Applied Art (Budapest, Hungary, inventory number 78.146.1; Gruia 2013, 354). St. George on horseback 

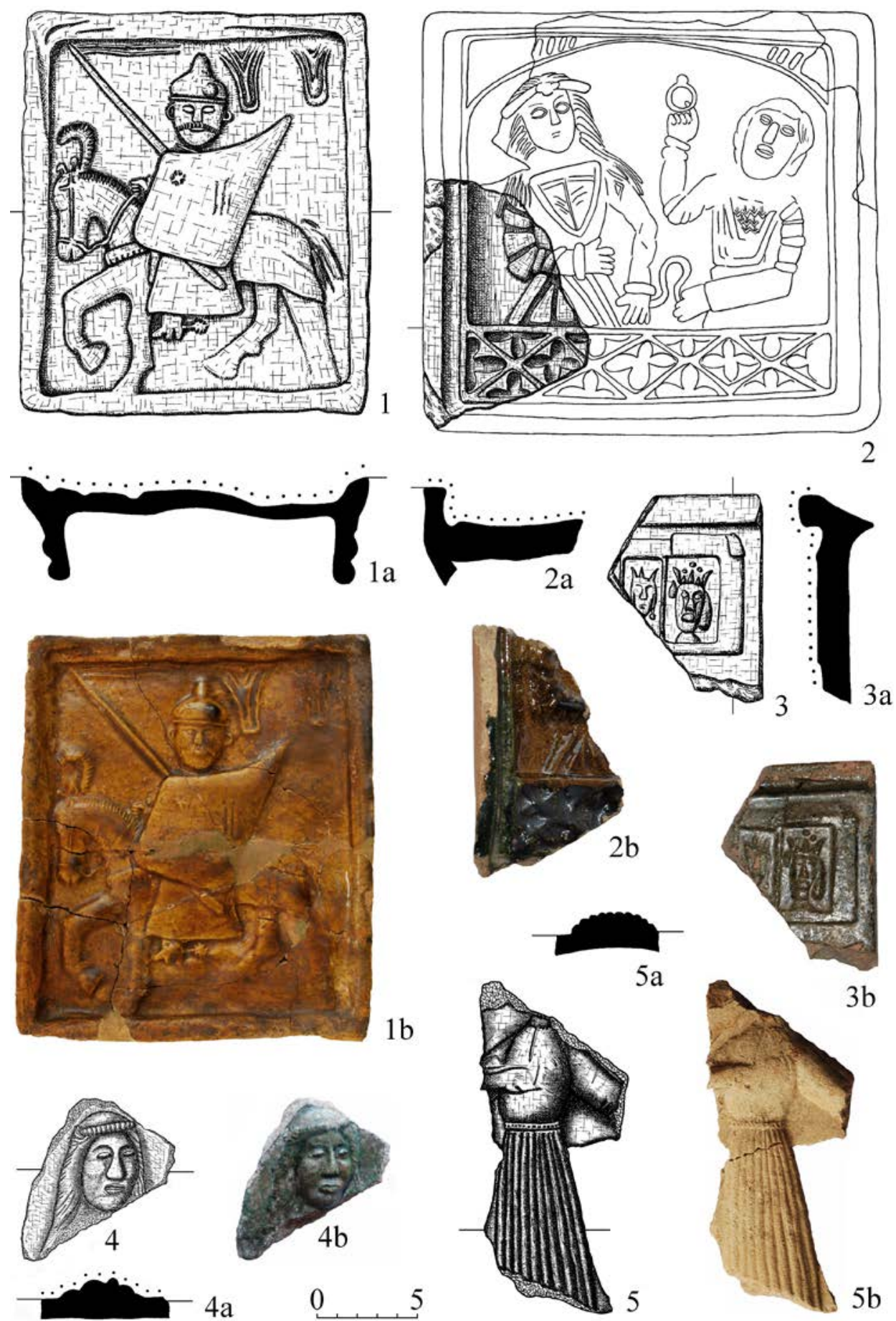

$0 \ldots 5$
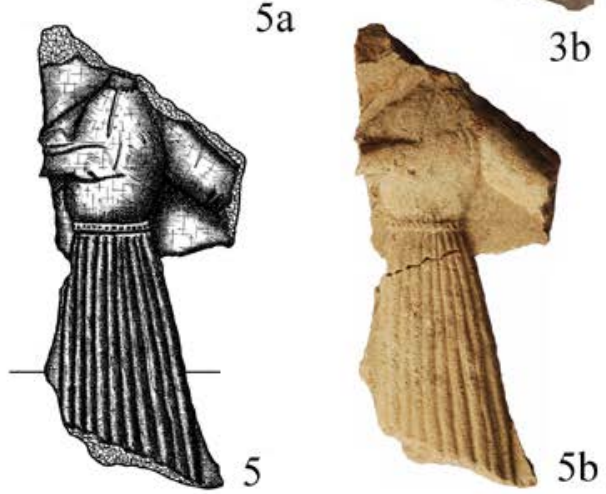

Fig. 8. Korolevo - the castle of Nyaláb. Panel tiles with anthropomorphic images. Obr. 8. Korolevo - hrad Nyaláb. Komorové kachle s antropomorfními motivy. 

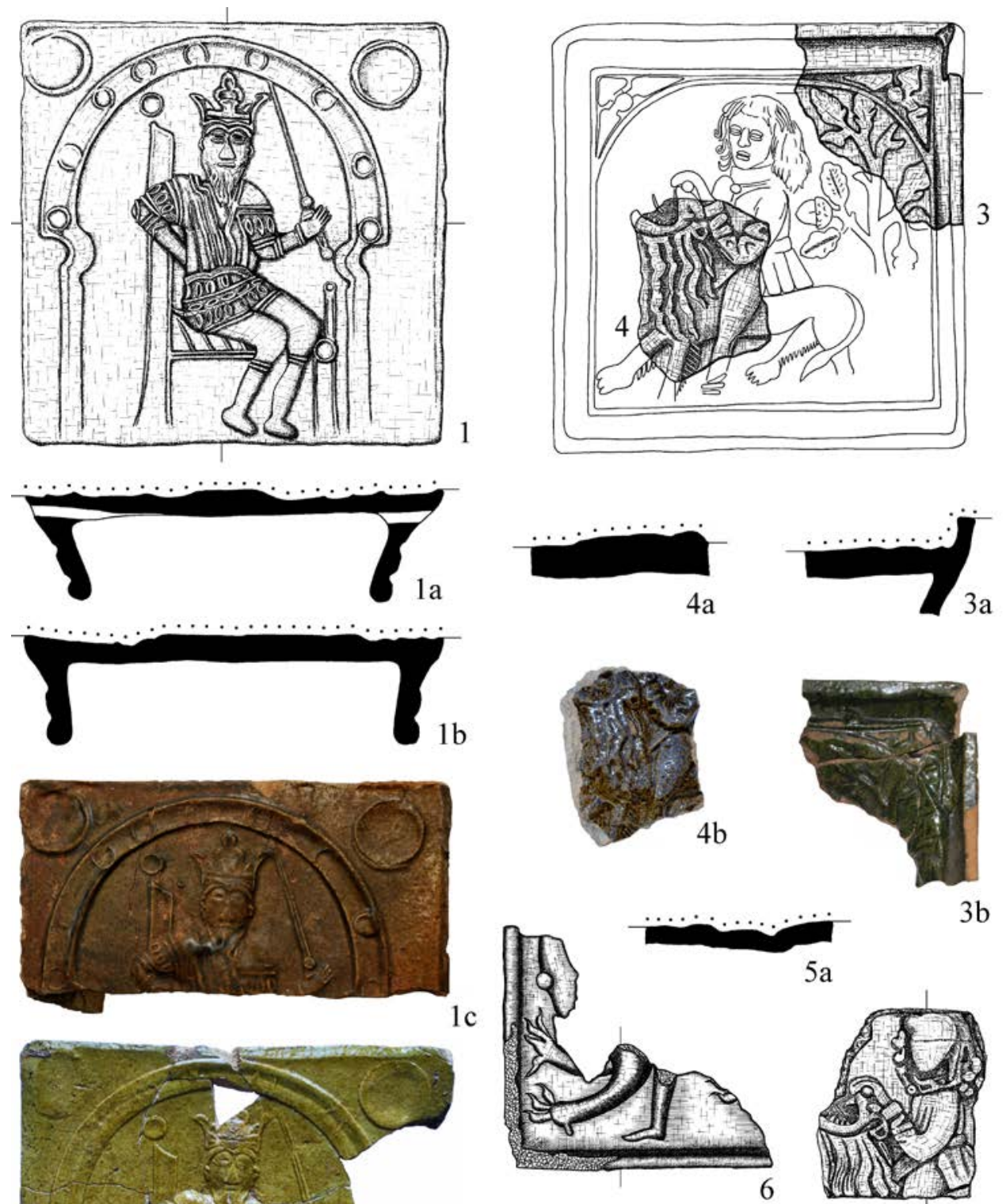

$1 \mathrm{c}$
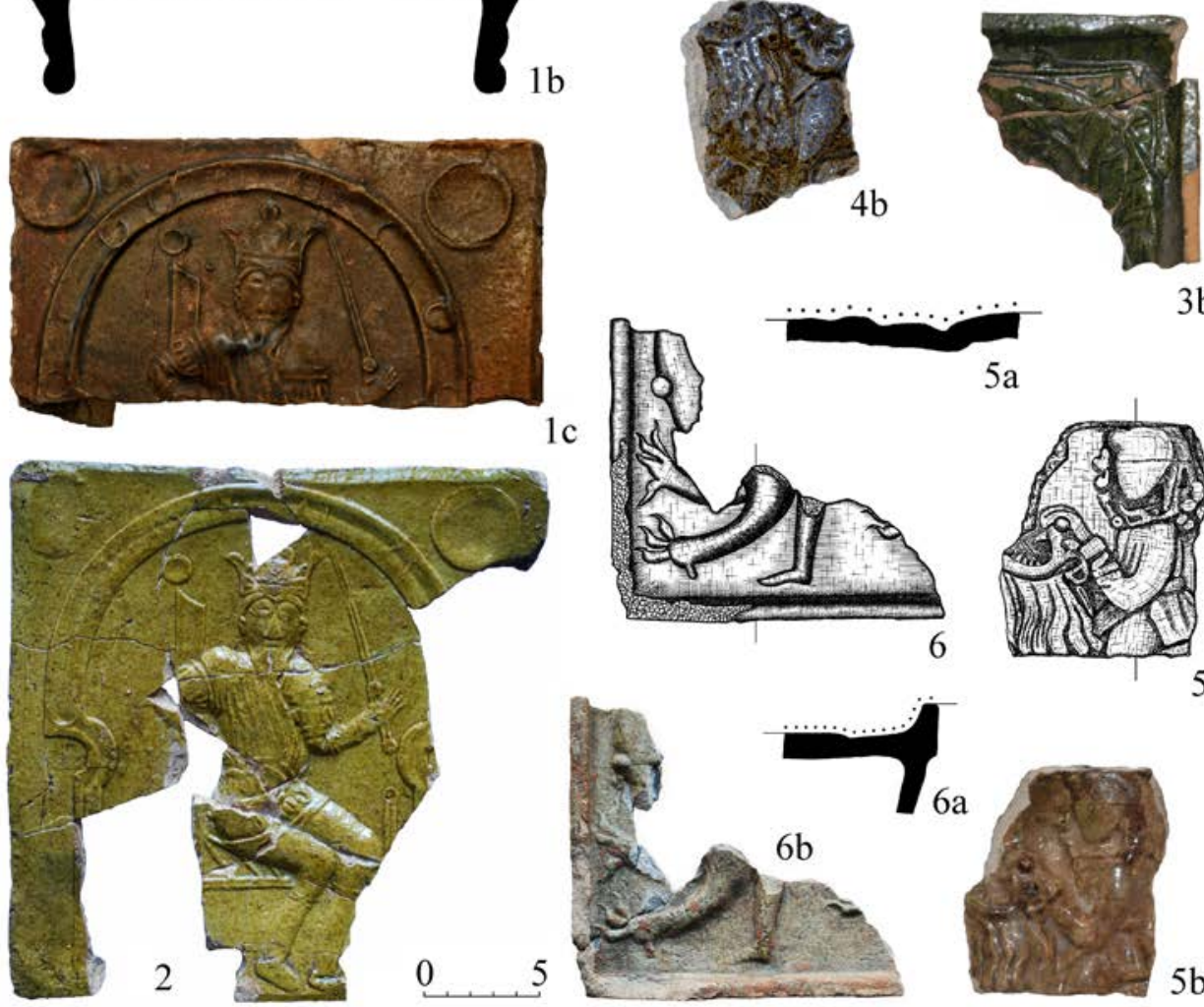

$5 \mathrm{a}$
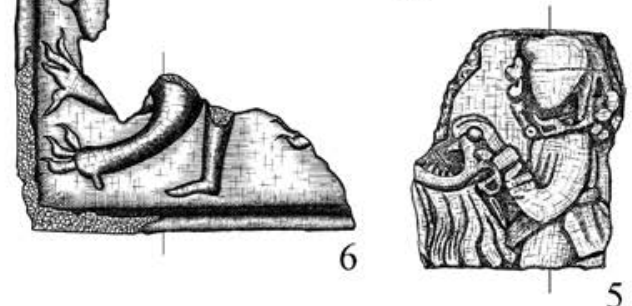

Fig. 9. Korolevo - the castle of Nyaláb. Panel tiles with Biblical motifs.

Obr. 9. Korolevo - hrad Nyaláb. Komorové kachle s biblickými motivy. 

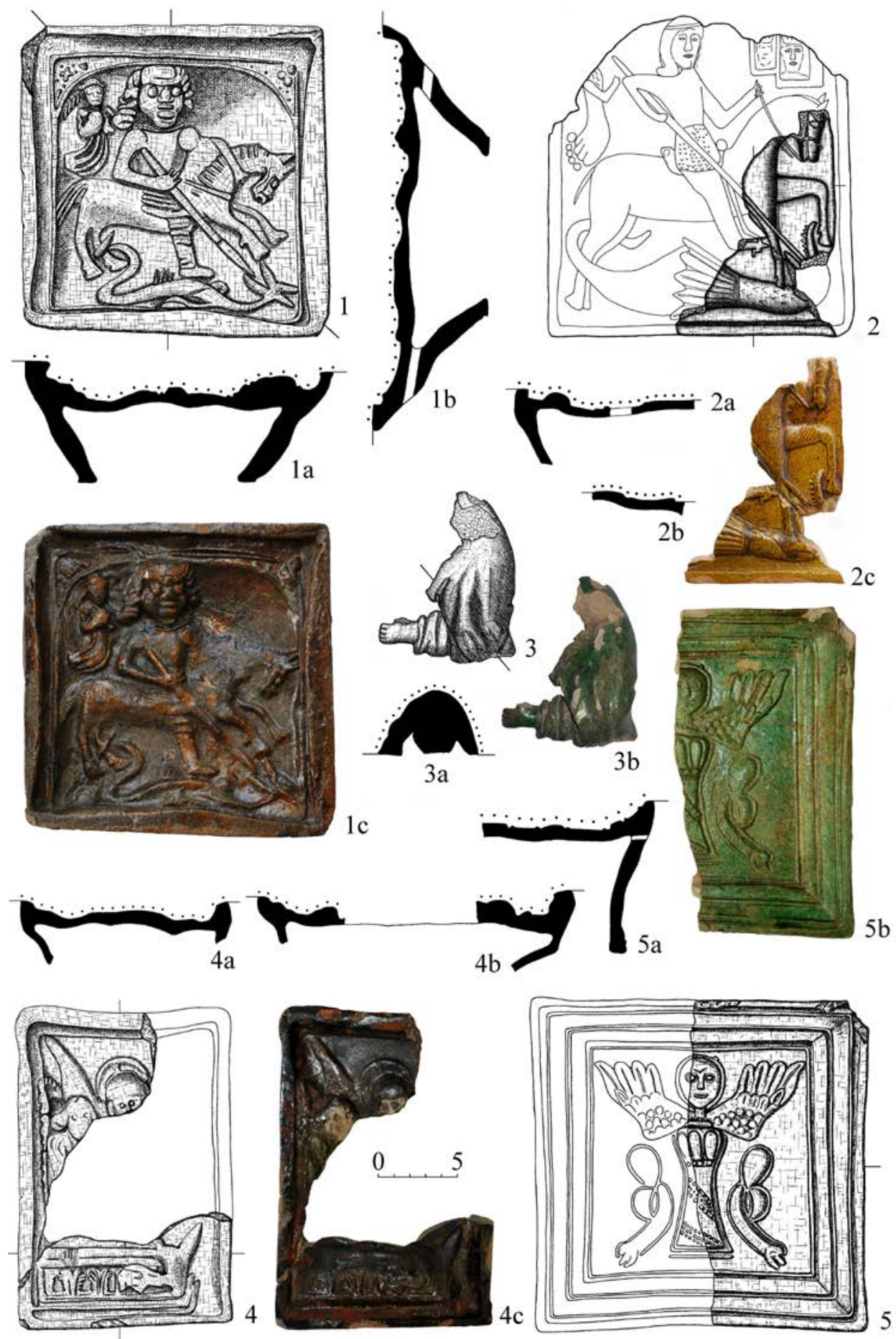

Fig. 10. Korolevo - the castle of Nyaláb. Stove-tiles with religious images.

Obr. 10. Korolevo - hrad Nyaláb. Komorové kachle s náboženskými motivy. 
piercing a dragon with a spear is in the center of the composition. Unlike the previous group of stove-tiles from Nyaláb, George does not wear armour. He holds the spear in his right hand and sends it to dragon's mouth. Away from the main scene, beside a princess, the faces of a king and a queen are depicted in the background in the upper right corner (Fig. 10:2).

There is only one example of an anthropomorphic statue in the collection of religiously oriented stove-tiles. It is green glazed item with the following parameters: height of the preserved part $-10.6 \mathrm{~cm}$; width $-8.3 \mathrm{~cm}$. It depicts a left hand bent in the elbow, with broken fingers. Clothing features, position of the palm and a print on the shoulder suggest that this image can be identified as the Virgin Mary holding baby Jesus (Fig. 10:3). This type of items was first found in Transcarpathia. It belongs to quite rare products - free-standing clay sculptures which were more typical of Western Europe. Their limited examples are known from Hungarian fortresses and royal castles of Diósgyör, Visegrád, Tata, Buda, etc. from the 14th century onwards. All sculptures were moulded separately and therefore were very different.

A fragment of a panel stove-tile covered with polychromic glaze (brown and green) is another single find. It depicts the Virgin Mary with Jesus. The front is rectangular in shape $(16.9 \times 24.9 \mathrm{~cm}$; Fig. 10:4).

Besides other items of religious subjects, it is worth mentioning a half of a green glazed panel depicting an angel. Its external surface is approximately square in shape $-21.0 \times 21.1 \mathrm{~cm}$ (Fig. 10:5).

A separate and large group of stove-tiles from the castle of Korolevo consists of finds with heraldic symbols (the coats of arms of King Matthias I Corvinus, the Perényi family and the Habsburgs). According to a precise definition by Š. Holčík, looking at a coat of arms warmed the owners up even if the stove was not hot (Holčík 1978, 12). This definitely only applied to the owner of the castle and his high-ranking guests.

Sometimes the stove-tiles depicting a coat of arms of a deceased ruler were used, too. Obviously, they were used as décor and did not bear any special content. Stove-tile fragments from the 16th century depicting heraldic symbols of King Matthias I Corvinus represent this category at the castle of Nyaláb. First of all, there are two green glazed pieces of panel tiles with the image of heraldic lion. Intact examples from the same mould from Cluj (Romania; Gruia 2012, 32-34; Rusu $2012,313-326$ ) suggest that their exterior was square in shape $-21.3 \times 21.8 \mathrm{~cm}$. Their artistic composition consists of heraldic shield which incorporates a smaller shield of the Hungarian Kingdom, and a raven holding a ring in its beak above the bigger shield. Two lions turning into opposite directions and standing on one leg hold a crown over the raven. A row of decorative triangles is located in the upper part of the bigger shield (Fig. 11:1-3). A raven holding a ring in its beak is the main symbol of the noble family of Hunyadi. A charter of Hungarian King László V Postumus (1445-1457), dated by February 1, 1453, describes the granting of a count's title to Hunyadi János and the enlargement of his coat of arms (National Archive of Hungary, № DL 24762).

Nyaláb is the only place where stove-tiles with the coat of arm of the Perényi family, one of the most influential in Hungary, was found. The finds are represented by three moulds. The first one is unglazed panels, approximately square in shape $-18.3 \times 19.4 \mathrm{~cm}$, depth $-7.2 \mathrm{~cm}$. A heraldic shield surrounded by floral décor is depicted on them. A profile of a bearded man turned to the right and holding a crown is on the shield (Fig. 11:4). Two other fragments are of crest tiles from the upper framing of a stove. The first one is a piece of a coarse polychrome stove-tile covered with dark green, light green, orange and black glaze. The second one is green glazed. Both tiles have the image of the mentioned man's head with a beard and braid. The polychromed item has a date with the profile - 1578 (Figs. 11:5-6).

Despite the fact that this image was found on stove-tiles for the first time, it is well known from epitaphs from Abaújvár, Košice, Rudabánya and Trebišov (Héczey-Markó-Rácz 2013, 55-71; Csoma-Csergheö 1888, 295-303; Dercsényi-Gerö 1963, 41, 43, 56; Slivka-Vallašek 1991, 212; Chovanec-Dronzek-Bajus 2004, 10, 13, 73, 74). The Perényi coat of arms was also represented in the decoration of the halls in the castles of Sárospatak, Siklós and Korolevo. It was on the seals of the family members and in the books of Janus Pannonius and Komjáti Benedek. 

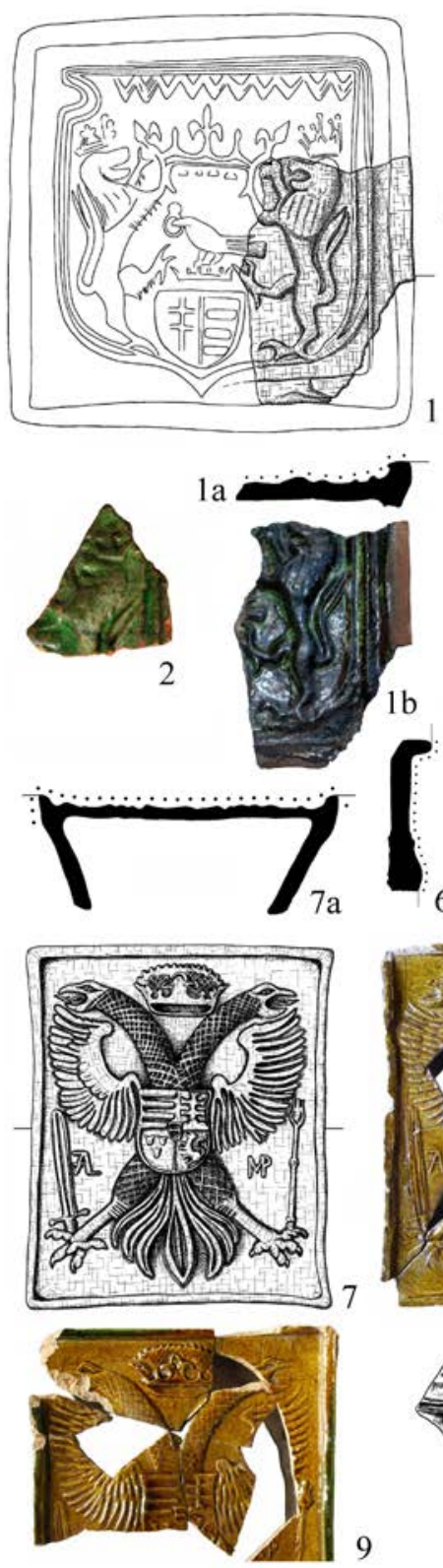
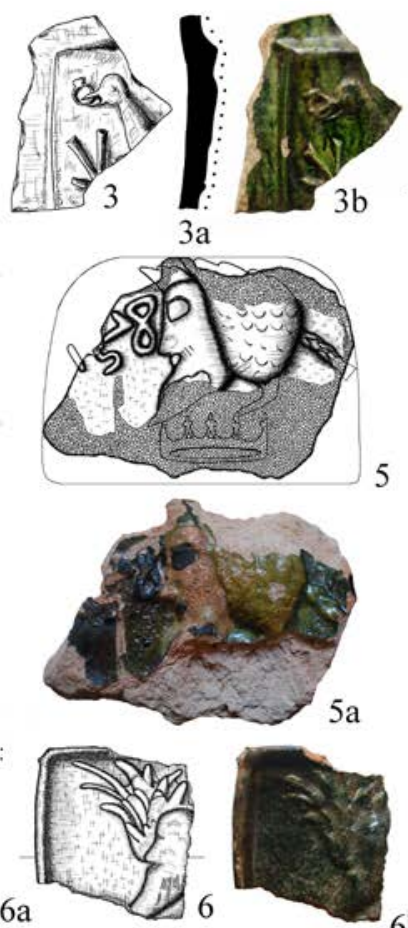

6

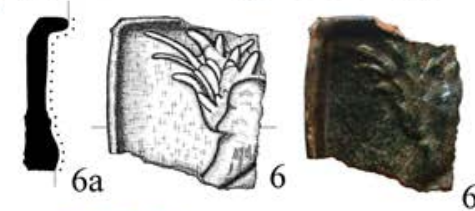

5
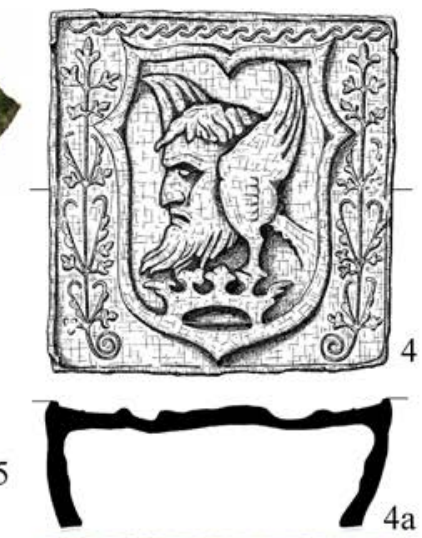

$6 b$
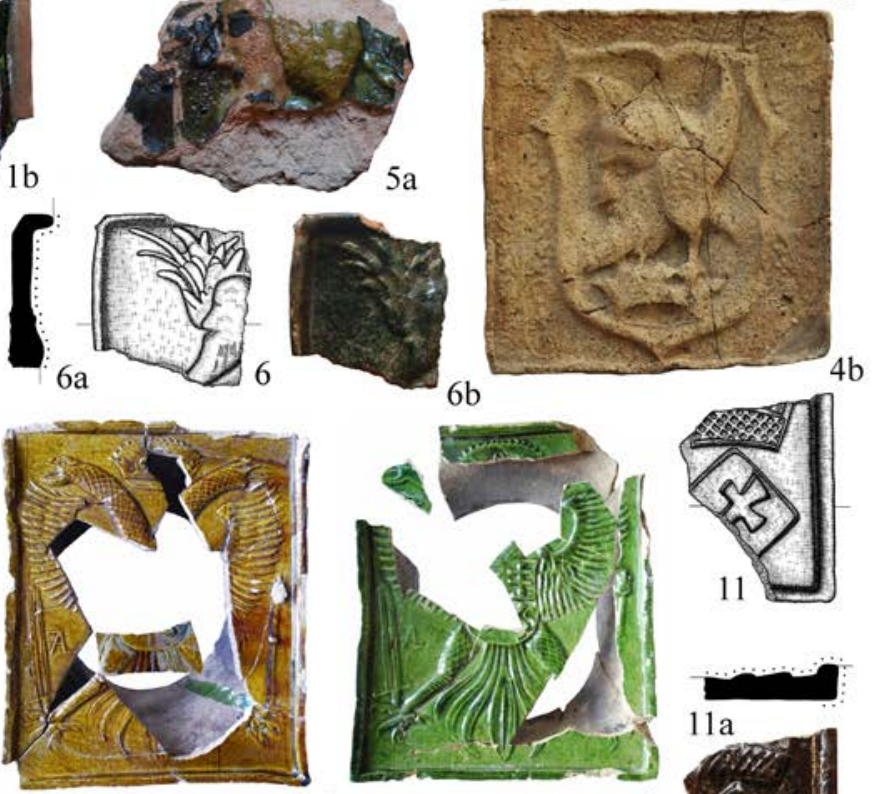

8
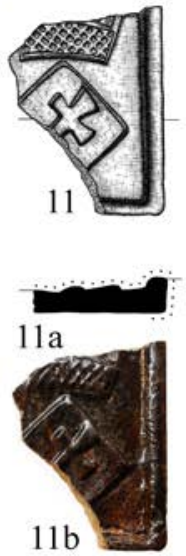

$10 \mathrm{~b} \quad 0 \quad 5$

Fig. 11. Korolevo - the castle of Nyaláb. Stove-tiles with heraldic symbols. Obr. 11. Korolevo - hrad Nyaláb. Komorové kachle s heraldickými motivy.

The Habsburg coat of arms with a double-headed eagle spreading the wings and tail is depicted on four stove-tiles. Its claws are extended apart, it holds a sword in the right one and scepter in the left. The heraldic shield with the Hungarian emblem is placed on the bird's chest and a crown is overhead. There are letters "A" next to the sword and "DM", meaning Anno Domini, near the scepter. The items are glazed in green or light brown. In one case both colors are present. The parameters are as follows: width $-16.6 \mathrm{~cm}$; height $-20.7 \mathrm{~cm}$ (Figs. 11:7-9). 

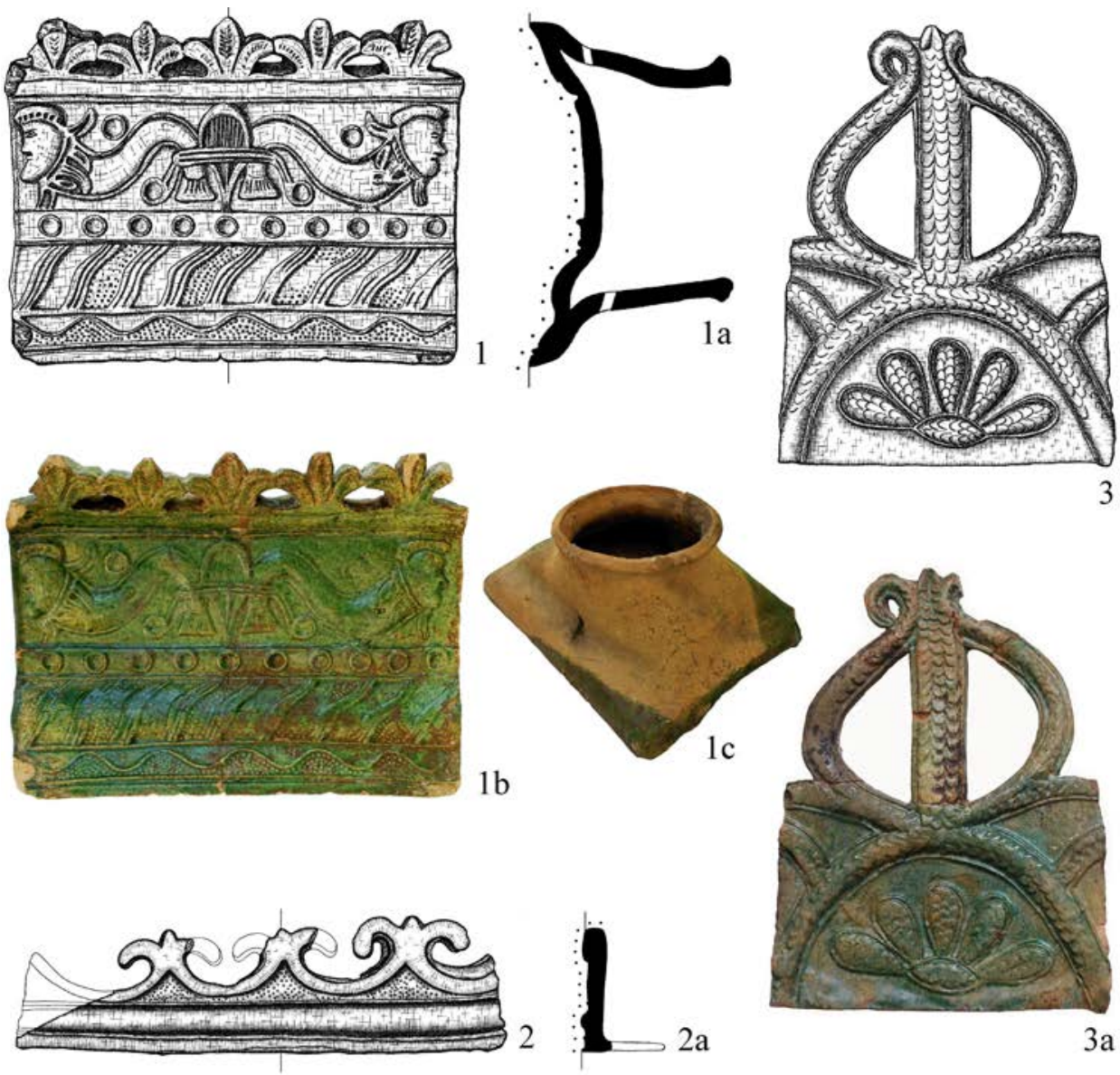

$$
\text { a }
$$
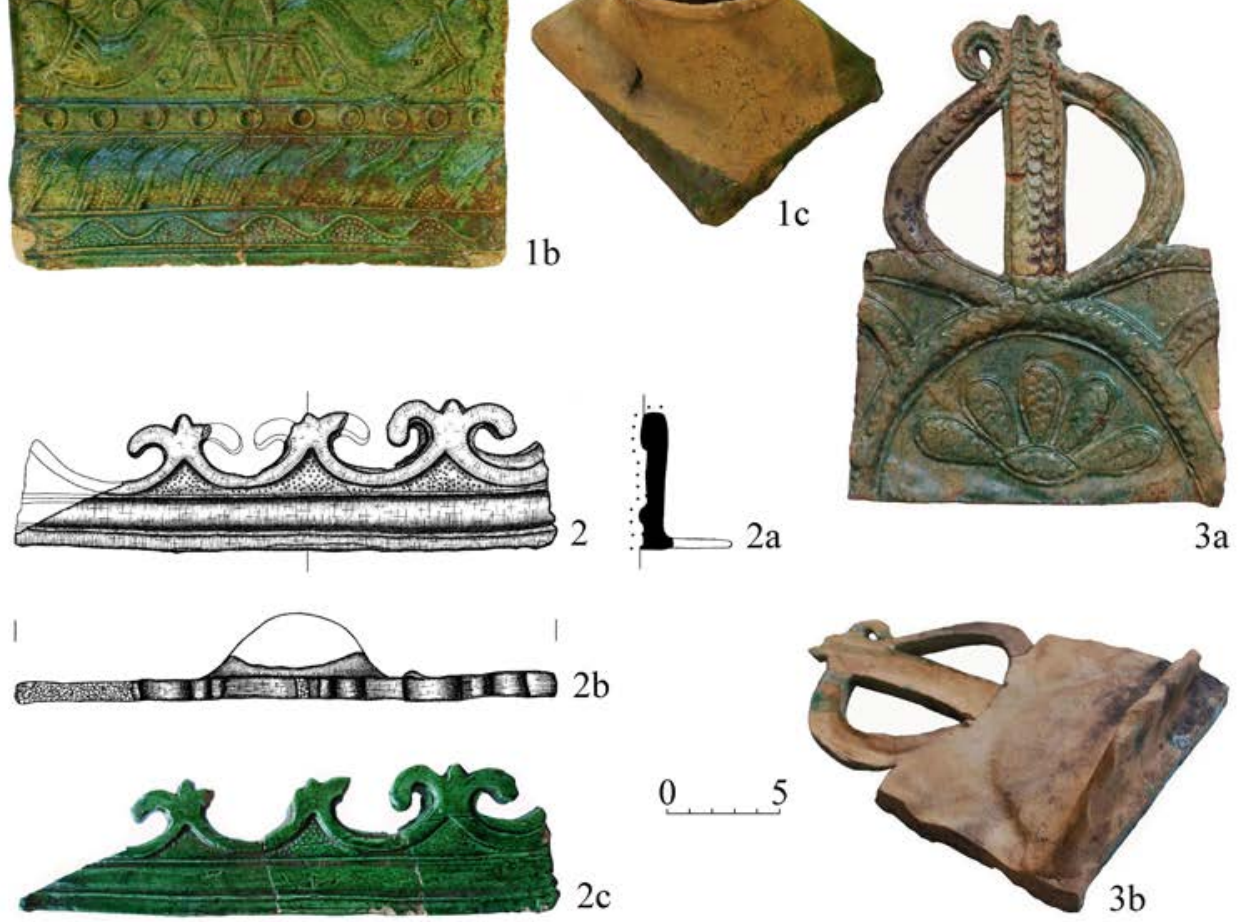

Fig. 12. Korolevo - the castle of Nyaláb. Crest tiles of the upper edging of the stoves.

Obr. 12. Korolevo - hrad Nyaláb. Ř́msové kachle a římsové korunní prořezávané nástavce s opěrnou lištou.

Based on archaeological materials from Hungary, Romania and Slovakia, K. Kozák argues that earlier images depicted the eagle with the crown on its head but not overhead and with neither a sabre nor mace in his claws. The wings' edges always pointed to the bottom corners. However, it was very rare for stove-tiles of the 17th and 18th centuries to portray the eagle without a weapon in his claws. From that time on its wings' edges always pointed to the upper corners (Kozák 1963, 65-200). These observations suggest that the finds from Korolevo can be dated to the first half of the 17 th century. 

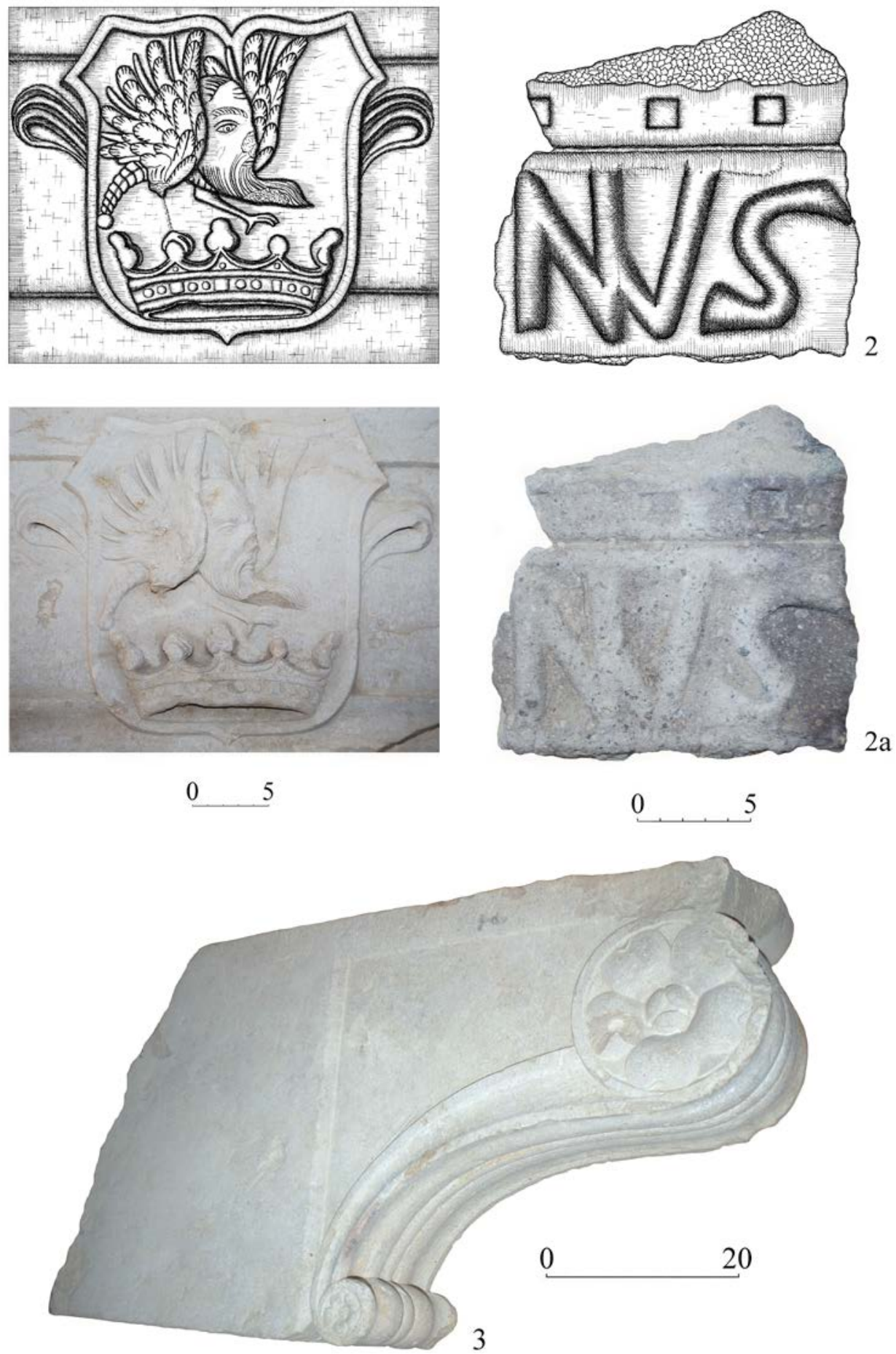

Fig. 13. Korolevo - the castle of Nyaláb. The elements of stone décor. Obr. 13. Korolevo - hrad Nyaláb. Kamenné architektonické prvky. 
A significant number of remains are crest stove-tiles of the upper framing of the stove. Only three moulds can be restored.

The first one is a panel covered in green glaze. The surface is decorated with anthropomorphic and zoomorphic images (two fishes with human heads turned in opposite directions and intertwined with the tails). A set of merlons is located above the main scene. The items are rectangular in shape $-17.2 \times 22.1 \mathrm{~cm}$, depth $-7.0 \mathrm{~cm}$ (Fig. 12:1).

A single copy of a stove-tile in the form of a panel is equipped with a half-oval ledge-stand on the back. Its surface is green-glazed. The stove-tile is crowned with three merlons in the form of a licentious bud of lily. Its parameters are: width $-24.6 \mathrm{~cm}$; height $-6.3-6.9 \mathrm{~cm}$ (Fig. 12:2).

The next type is a set of rectangular panel-shaped tiles from stove 4 . They are also equipped with half-oval ledge-stands. The items are covered in scales-like décor and a $11.5 \mathrm{~cm}$ tall harp-like mould. The panels' parameters are as follows: height $-10.1 \mathrm{~cm}$; width $-15.3-15.6 \mathrm{~cm}$ (Fig. 12:3).

Numerous polished relief stone slabs were found among the fragments of the wall near tile stove 4. The Perényi family coat of arms (a profile of a flying bearded man's head turned to the left holding a crown) is depicted on one of them (Fig. 13:1). Fragments of polished blocks with floral décor (Fig. 13:3) and a piece with part of inscription “...NVS...” were discovered as well (Fig. 13:2).

A rich collection of small finds of metal, glass and bone was gathered at the castle of Korolevo. A heavy, $1.78 \mathrm{~g}$, bronze medallion is one of the most informative among them. It consists of a round plate (diameter $-1.7 \mathrm{~cm}$ ) with an image and a hanging loop. The front features the profile of Saint Ignatius of Loyola with the legend .S.IGMA.SIS, and the reverse a full-face image of Saint Francis Xavier with the legend .S.FRANCI.XAVR (Fig. 14:1). According to Slovak scientist J. Hunka, such Jesuit medallions had been produced since the 17th century but were the most widespread in the first half of the 18th century. Considering the date of sanctification of Ignatius of Loyola and Francis Xavier (1622) as well as the period of the destruction of Nyaláb (1671-1672), the medallion from the castle of Korolevo can be dated to the middle of the 17th century. It is worth mentioning that is was not produced in a specialized workshop but in a jeweller's one. The poorly educated craftsman made a mistake in spelling the name Ignatius, which turned into Igmatius. The smudged faces of the saints without distinct features should be also mentioned.

A copper token (abacus count) draws attention among other metal products excavated the castle (Fig. 14:2). J. Hunka identified the item as follows: Germany, Nuremberg, rechenpfenig, 1490-1550. An English style ship is depicted on one side and the state emblem of France with lilies on other side of the token. A set of Gothic letters of unidentifiable inscription is stamped around the images (Mitchiner 1998, 365).

A belt buckle copper plate stands out among other sets identified at Nyaláb. It is rectangular in shape $(2.4 \times 1.4 \mathrm{~cm})$. The preserved fragment has the inscription ...EVILLEMOI... in the central part within a linear frame. The letters are stamped in Gothic fonts. Above and beyond them the belt buckle is decorated with convex spiral ornament (Fig. 14:3). Taking into account that such belt buckles (inscription style - Gothic script) did not exist in the 14th century and was rare at the beginning of the 16th century, the item can be dated to the 15th century.

Two similar finds were discovered in the territory of north-eastern Hungary (Szer monastery and Orgondaszentmiklós burial ground). O. Trogmayer restored the inscription on them as DE VILLEMONT and related it to French builders (Trogmayer 2001, 259-263). Similar interpretation of analogies as well as the dating of a specimen from Korolevo suggest the participation of French masons in the rebuilding of the castle of Nyaláb. The following facts also support this assumption. A significant number of 15th-century arch-type structures at Nayláb were built with tuff, which required this category of workers - masons. A mason's set of tools, two chisels with different cutting edges, was found near the fragment of the belt buckle.

Half of a textile lead seal confirms trade contacts of the inhabitants of the castle of Korolevo (Fig. 14:4). Despite a large number of such finds in Hungary, it is only the second example found in Transcarpathia. Considering seal inscription, it apparently originated from Flanders. The stylistics and typology date it to the 15th century at the earliest and to the turn of the 15th and 16 th centuries at the latest. 


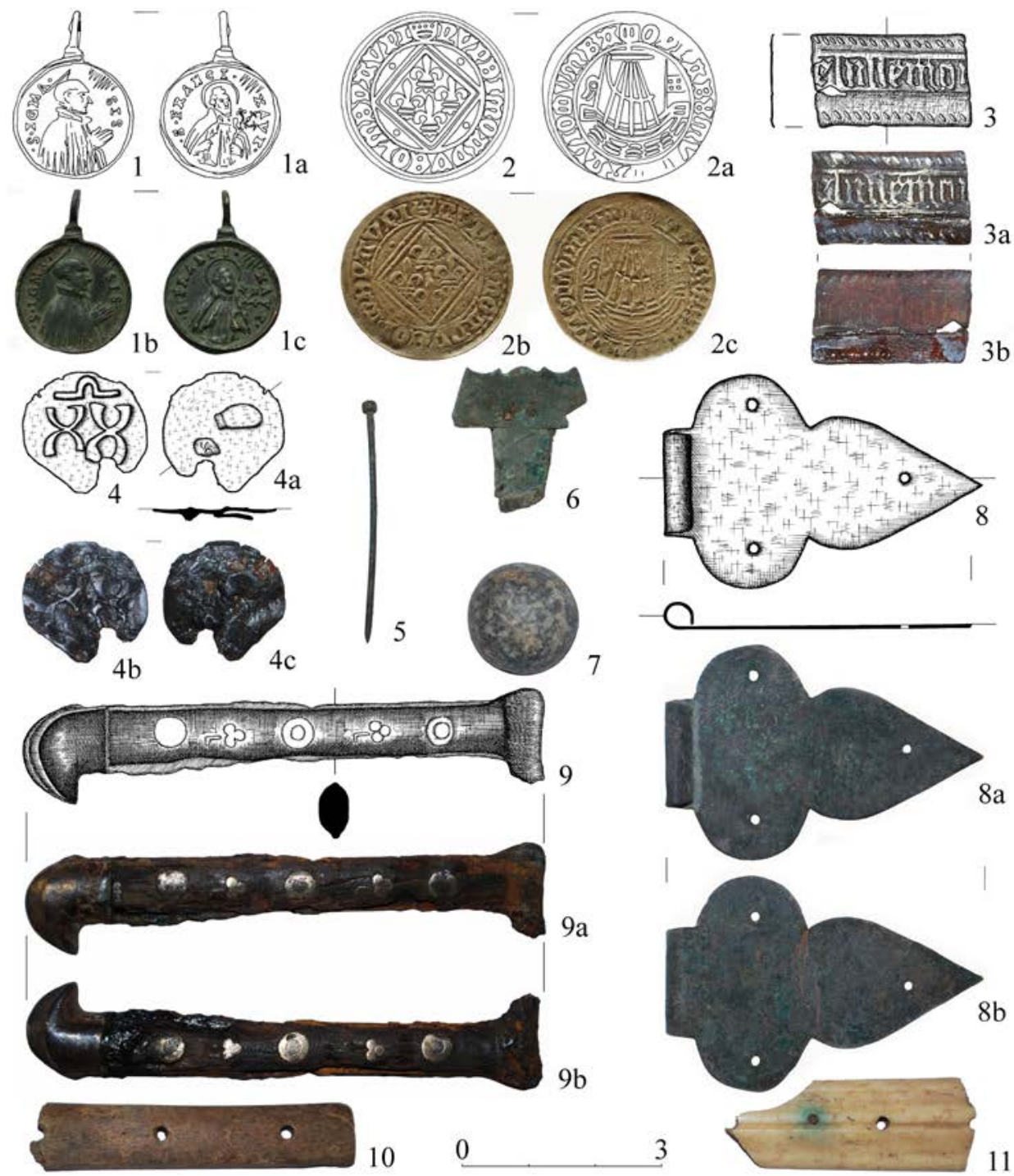

Fig. 14. Korolevo - the castle of Nyaláb. Small finds.

Obr. 14. Korolevo - hrad Nyaláb. Drobné nálezy.

A $8.1 \mathrm{~cm}$ long knife handle stands out among the items of cutlery. A small broken blade of a sharp triangular form has remained in the tang slot. The blade tang is made of iron plate (thickness $-0.1 \mathrm{~cm}$, width $-1.0 \mathrm{~cm}$ ) with a beak-like rear copper bolster. Its spine is furrow-stitch decorated. Wooden handle scales are decorated with copper insertion in the form of playing cards clubs. They are attached to the tang by three copper handle pits (Fig. 14:9).

A collection of coins found at Nyaláb is also significant. It consists of two dozen items. Chronologically it spans the 14th and the 17th centuries with evident dominance of Hungarian denominations (Figs. 15:1-18). There are only two milled coins from Poland (Figs. 15:19-20). The denarii of Ferdinand I (type Huszár, 935) which were widespread all over the territory of historical Hungary prevail among the finds. Thousands of similar denominations from 1526-1564 were parts of treasure troves. 

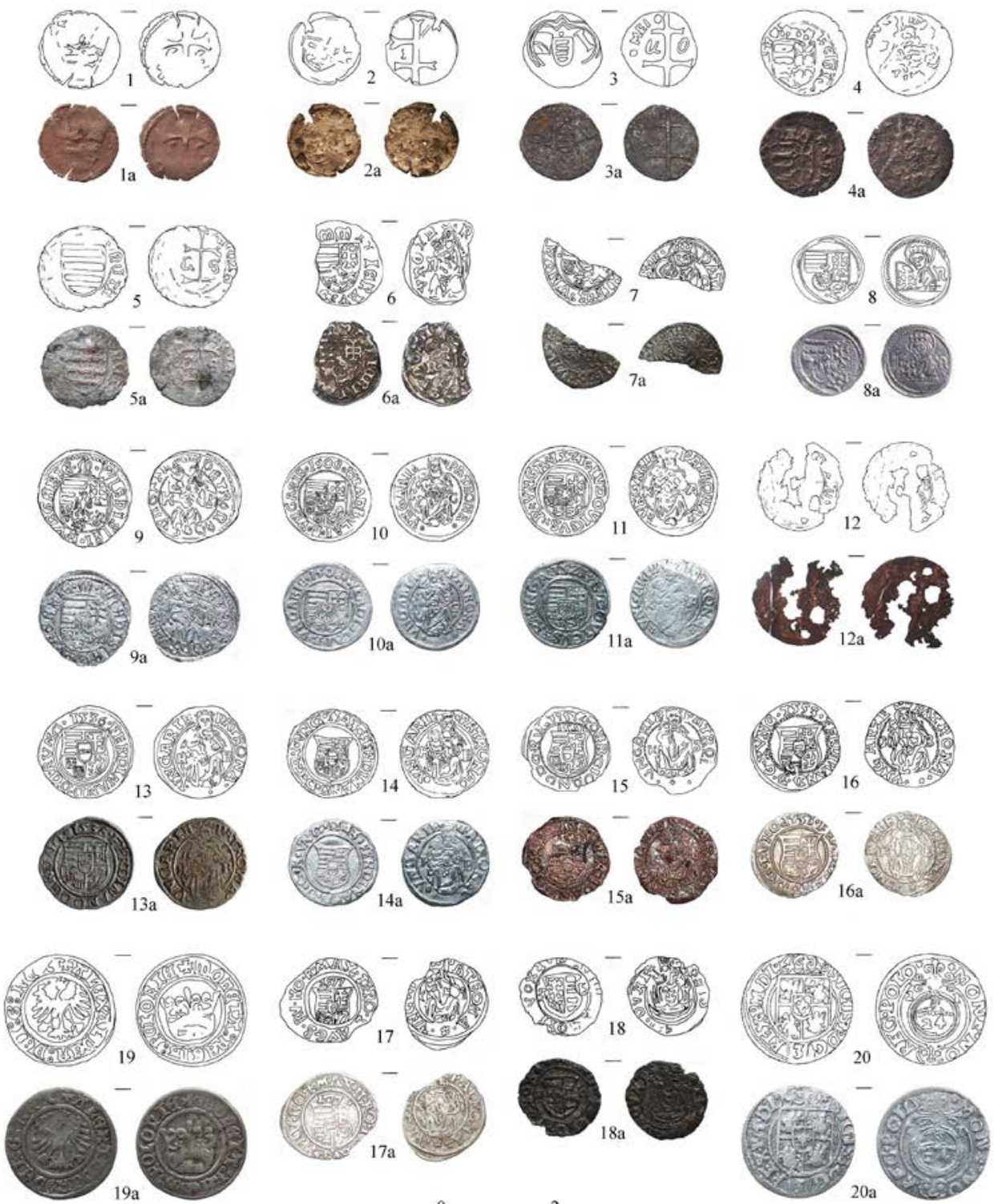

Fig. 15. Korolevo - the castle of Nyaláb. Coins. Obr. 15. Korolevo - hrad Nyaláb. Mince.

A phenomenon of numerous counterfeit coins from the 16th century in the territory of north-eastern Hungary is mentioned in numismatic literature. Silvered copper forgery of denarii of Louis I (Fig. 15:12) and Ferdinand I (Fig. 15:15) represent this group at the castle of Nyaláb.

A find of a Polish coin of Sigismund III Vasa (1587-1632) discovered under the stone obstruction in the depth of $4.5 \mathrm{~m}$ provides important information about the time of the demolition of the castle walls. It is one and a half grosz from 1621 (weight $-1.11 \mathrm{~g}$, diameter $-19.0 \mathrm{~mm}$, mint - Bydgoszcz; Fig. 15:20). The item connects the stone obstruction and the final demolition of the walls in the 17 th century. 


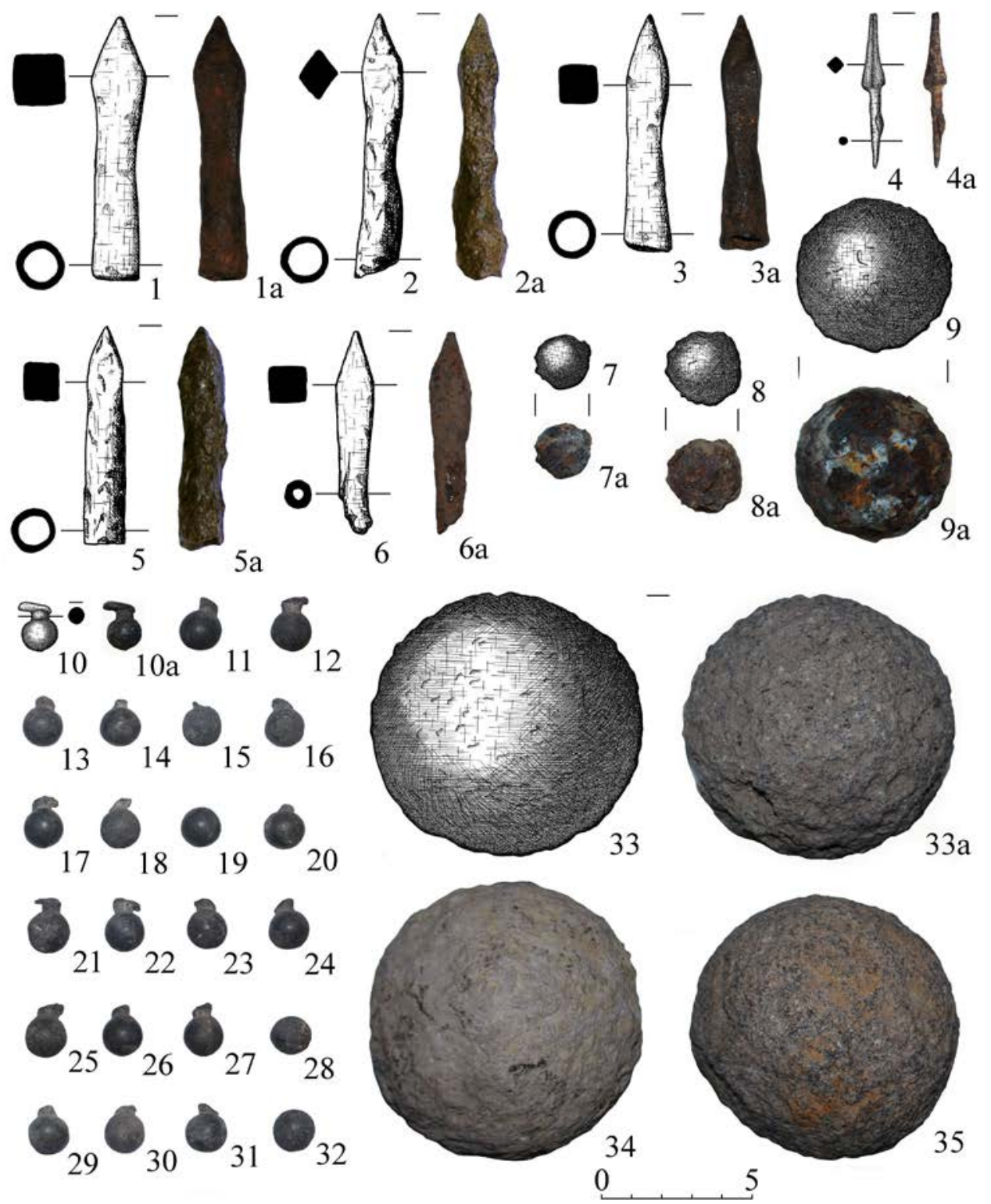

Fig. 16. Korolevo - the castle of Nyaláb. Armaments. Obr. 16. Korolevo - hrad Nyaláb. Zbraně a výzbroj.

Armaments (cannonballs, bullets, buckshot and crossbow arrowheads) comprise another group of finds at the castle of Korolevo. Their analysis reflects the types of firearms and projectile used by defenders of Nyaláb and the storming troops.

The largest cannonballs are made of porous but solid stones. Their diameters are $8.5-9.0 \mathrm{~cm}$ (Figs. 16:33-35). Few parts are cracked from one side of the sphere. This suggests that they were broken in impact with the stone wall. Moreover, it indicates the usage of medium calibre cannons during the siege of the castle. An iron cannonball $(4.6 \mathrm{~cm}$ in diameter) proves the usage of 
light cannons of small calibre by the attackers (Fig. 16:9). Assault forces were also armed with muskets that fired iron buckshot and bullets (diameter - 1.3 and $2.1 \mathrm{~cm}$; Figs. 16:7-8).

The use of crossbows by attackers is mentioned several times in scientific publications on the castle of Korolevo. Damaged projectile points were considered a proof of their usage on the battlefield (Прохненко-Гомоляк-Мойжес 2007, 219-255). Two types of crossbow arrowheads were defined.

Type I. These are iron, $5.1 \mathrm{~cm}$ long arrowheads of the split-shaft construction. Their projectile point is square and has extended pyramidal form. It is $2.5 \mathrm{~cm}$ long. The shaft is round and is more than half of the arrow's length $-2.6 \mathrm{~cm}$ (Fig. 16:4).

Type II. These are socket tang, $8.0-10.0 \mathrm{~cm}$ long arrowheads with square or rhombic projectile points (Figs. 16:1-3, 5-6).

It is worth mentioning that the defenders of Nyaláb had to use similar types of firearms and projectile. However, a musket of a small calibre is the only archeologically proven weapon of the castle's protectors. Locally produced leaden buckshot $(1.3 \mathrm{~cm}$ in diameter), with the risers remained after pouring metal to the mould, were excavated as well (Figs. 16:10-32).

Concluding the review of the castle's inventory, it is worth mentioning that the analysis of both the stratigraphic situation and the finds suggests the operation of Nyaláb fortifications from the end of the 13th century until the middle of the 17th century. This dating does not contradict the written sources. Undoubtedly, further archaeological studies and analysis of a large number of written sources will provide additional information and specify the history of this key fortification.

\section{Literature}

BENCZE, Ü., 2008: Importuri de vase ceramice central-europene în Transilvania. Secolele XIV-XVI. http://www.medievistica.ro/texte/arta. 7. 04. 2008.

ČAPLOVIČ, D.-SLIVKA, M., 1985: Stredoveká importovaná keramika na východnom Slovensku, AR XXXVII, 49-57.

CHOVANEC, J., 2005: Palatínska kachlová pec Imricha Perényiho. In: Gotické a renesančné kachlice v Karpatoch, 23-54, 257-259. Trebišov.

CHOVANEC, J.-DRONZEK, J.-BAJUS, L'., 2004: Kostol Navštívenia blahoslavenej Panny Márie v Trebišove. Trebišov.

CSOMA, J.-CSERGHEÖ, G., 1888: A Perényiek középkori síremlékei, Archaeologiai Értesítő VIII, 295-303.

DERCSÉNYI, D.-GERÖ, L., 1963: A sárospataki Rákóczi-vár. Budapest.

DROBNÁ, Z., 1957: Loštické poháry. K otázce jejich datování a slohového zařazení, Český lid 44, 98-107.

FELD, I., 2002: Gótikus és reneszánsz kályhacsempék Északkelet - Magyarországról. In: Gerencsérek, kályhások, tűzvigyázók. Feudáliskori kályhacsempék az Alföldről és peremvidékéről. Gyula.

GOŠ, V., 2007: Loštice - město středověkých hrnčírů. Opava.

GOŠ, V.-NOVÁK, J., 1976: Počátky výroby loštické keramiky, AR XXVIII, 4, 399-404.

GRUIA, A. M., 2006: Saint George on Medieval Stove Tiles from Transylvania, Moldavia and Wallachia. An Iconographical Approach, Studia Patzinaka 3, 7-48.

-2010: Winged Samson and popular iconography in sixteenth-century Transylvania, Acta musei Napocensis $47 / \mathrm{II}, 203-211$.

- 2012: Povestiri la gura sobei. Catalog selectiv al colecţiei de cahle a Muzeului Naţional de Istorie Transilvanei. Cluj-Napoca.

- 2013: Religious representations on stove tiles from the medieval kingdom of Hungary. Cluj-Napoca.

GYURICZA, A., 1992: Reneszánsz kályhacsempék Északkelet - Magyarországról. Miskolc.

HÉCZEY-MARKÓ, Á.-RÁCZ, M., 2013: Perényi Péter sírköve az abaújvári református templomban, Folia historica XXVIII, 55-71.

HOLČíK, Š., 1978: Stredoveké kachliarstvo. Bratislava.

HUSZÁR, L., 1979: Münzkatalog Ungarn von 1000 bis Heute. München.

ILOSVAI SELYMES, P., 1886: Az híresneves Tholdi Miklósnak jeles cselekedeteiről és bajnokságáról való história (bev. és jegyz. kísérte Szilády Áron). Budapest.

ISTRATE, D. M., 2004: Cahle din Transilvania şi Banat de la începuturi până la 1700. Accent.

KERAMISCHE BODENFUNDE AUS WIEN: Keramische bodenfunde aus Wien. Wien. 
KOMÁROMY, A., 2001: Nyalábvár és uradalma. In: Ugocsa vármegye a történelemben. Válogatott írások, 16-42. Ungvár.

KOZÁK, K., 1963: Kétfejű sasos kályhacsempék Magyarországon, Budapest Régiségei XX, 65-200.

KRÁSA, KTERÁ HŘEJE, 2008: Krása, která hřeje. Výběrový katalog gotických a renesančních kachlů Moravy a Slezska - Schönheit, die wärmt. Gotische und renessainzeitliche Kacheln aus Mähren und Schlesien (Menoušková, D.-Měřínský, Z., edd.), 117-137. Uherské Hradiště.

MITCHINER, M., 1998: The medieval Period and Nuremberg. Jetons, medalets at tokens. 1. London.

MIHOK, L.-PROCHNENKO, I., 2008: Analysis of Iron Objects from Korolevo and Vinogradovo Castles, Carpatica-Карпатика 37, 149-165.

NEKUDA, V.-REICHERTOVÁ, K., 1968: Středověká keramika v Čechách a na Moravě. Brno.

PAVLÍK, Č.-VITANOVSKÝ, M., 2008: Magický jednorožec a jeho ztvárnění na kachlích gotiky a renesance Die magische Einhorn und seine Gestaltung auf Kacheln der Gotik und der Renaissance, AH 33, 539-558.

POLLA, B., 1986: Košice Krásna. K stredovekým dejinám Krásnej nad Hornádom. Košice.

PROHNENKO, I.-MOJZSESZ, V.-ZSILENKO, M., 2012: A királyházai vár csempekályhája, A nyíregyházi Jósa András Múzeum Évkönyve LIV, 241-285.

- 2013: Kárpátalja középkori és kora újkori várainak kutatsá, A nyíregyházi Jósa András Múzeum Évkönyve LV, 203-250.

RUSNAK, R., 2014: Vývoj mestskej domovej parcely na príklade Mäsiarskej 57/A v Košiciach, SlArch LXII, 315-398.

RUSU, A. A., 2012: Stove Tiles with the Royal Coat of Arms of King Matthias I Corvinus, Ephemeris Napocensis XXII, 313-326.

SCHARRER-LIŠKA, G., 2007: Die hochmittelalterliche Grafitkeramik in Mitteleuropa und ihr Beitrag zur Wirtschaftsgeschichte. Römisch-Germanisches Zentralmuseum Mainz 68. Mainz.

SLIVKA, M.-VALLAŠEK, A., 1991: Hrady a hrádky na východnom Slovensku. Košice.

SZÉKELY, T., 1957: A magyar bibliafordítások történetéből. Budapest.

TROGMAYER, O., 2001: Villemont úr rejtélyes övei, A nyíregyházi Jósa András Múzeum Évkönyve XLIII, 259-263.

ULIČNÝ, M., 2004: Premeny východoslovenskej keramiky v 13.-17. storočí [na podklade analýzy keramického fondu z hradu Šariš], dissertation thesis (Archeologický ústav SAV v Nitre), Prešov.

МИКИТАСЬ, В.-ЧУЧКА, П., 1968: Дві Закарпатські оригінальні пам’ятки XV ст., Мовознавство 1, $62-64$.

МОЙЖЕС, В., 2014: Дослідження багатошарового поселення Ужгород-Горяни в 2013 p. In: Археологічні дослідження в Україні 2013, 133-134. Київ.

ПАМ'ЯТКА АРХІТЕКТУРИ XIV ст., 1993: Пам'ятка архітектури XIV ст. Руїни замку в смт. Королево Виноградівського р-ну Закарпатської області. Топогеодезичні пошукові роботи і археологічні науково-дослідні роботи. Том II. Книга 5. Вип. І. Шифр 93-41; II-5-І. Львів.

ПРОХНЕНКО, И., 2007: Новые данные о восточной границе распространения керамики типа Лоштице, Východoslovenský pravek VIII, 105-110.

- 2008: Меч с Королёвского замка, Саrрatica-Карпатика 37, 186-188.

- 2009: К вопросу о создании средневековых фортификационных сооружений на территории Закарпатья, Východoslovenský pravek IX, 205-208.

ПРОХНЕНКО, І., 2013: Знахідки лоштицького посуду на руїнах Королевського замку. In: Ужгородські чеські наукові читання: історія, культура, політика, право. Науковий збірник, 32-39. Ужгород.

ПРОХНЕНКО, І.-ГОМОЛЯК, О., 2007: Дослідження Виноградівського та Королівського замків у 2007 році. In: Relaţii româno-ucrainene. Istorie şi contemporaneitate. Румунсько-українські відносини. Історія та сучасність, 83-94. Cluj-Napoca - Satu Mare.

- 2009: До історії замків Закарпаття, Військово-історичний альманах 1(18), 71-97.

- 2013: Дослідження Королівського замку в 2011 р. In: Археологічні дослідження в Україні 2012, 170-171. Київ-Луцьк.

- 2013а: Розкопки Королівського замку в 2012 р. In: Археологічні дослідження в Україні 2012, 171-172. Київ-Луцьк.

ПРОХНЕНКО, И.-ГОМОЛЯК, Е.-МОЙЖЕС, В., 2007: Результаты исследования Виноградовского и Королёвского замков в 2007 году, Carpatica-Карпатика 36, 219-255.

- 2008: Результаты исследования Броньковского замка, Carpatica-Карпатика 37, 139-148.

- 2011: Результаты исследования замков Закарпатья, Satu Mare, Studii şi comunicări. Seria archeologie XXVII/I, 187-234.

- 2011а: Результаты исследования Королёвского замка в 2011 году, Карпатика 40, 213-232.

ПРОХНЕНКО, І.-ГОМОЛЯК, О.-МОЙЖЕС, В., 2009: Результати дослідження Виноградівського і Королівського замків. In: Археологічні дослідження в Україні. 2006-2007, 296-301. Київ. 
ПРОХНЕНКО, І.-МОЙЖЕС, В.-ГОМОЛЯК, О., 2012: Дослідження замків Закарпаття археологічною експедицією Ужгородського національного університету, Історичні студії. Збірник наукових праць з проблем давньої і середньовічної історії та етнології 4, 59-78.

ПРОХНЕНКО, И.-МОЙЖЕС, В.-ЖИЛЕНКО, М., 2012: Результаты исследования Королёвского замка Нялаб в 2012 году, Карпатика 41, 204-248.

ПРОХНЕНКО, І.-МОЙЖЕС, В.-ЖИЛЕНКО, М., 2013: Біблійні сюжети на кахлях Королівського замку, Наукові записки Ужгородського університету. Серія: історично-релігійні студії 2, $142-151$.

- 2013а: Єзуїтський медальйон з Королівського замку, Наукові записки Ужгородського університету. Серія: історично-релігійні студії 2, 152-163.

ПЬЯНЧАК, П.-ПРОХНЕНКО, И., 2008: Анализ остеологического материала замков северо-восточной части Верхнего Потисья, Саrpatica-Карпатика 37, 166-177.

\section{Shrnutí}

\section{Hrad Nyaláb v Korolevu}

Hrad Nyaláb, nacházející se na severozápadním okraji obce Korolevo Vinogradovského regionu, se vyznačuje složitou stratigrafií, silným kulturním souvrstvím a velkým množstvím nálezů. Hrad byl postaven na kopci vulkanického původu, vysokém 52 metrů. Kopec sám je geologickou záhadou, nebot' nejbližší kopce se nacházejí ve značné vzdálenosti od něj. Z jeho vrcholu je vidět údolí řeky Tiszy, která teče asi 300 metrů odtud. Čtvercová centrální část hradu má rozlohu $52 \times 47 \mathrm{~m}$ a tvar trapezoidu. Je situována v severozápadní části vyvýšené platformy. Třicet metrů od hlavní části hradu se nachází linie opevnění s obdélníkovou budovou. Bastion klínovité konstrukce byl postaven stranou hlavní části hradu, na jihozápadním okraji hradního křídla. Jeho rozměry jsou $10,15 \times 9,65 \mathrm{~m}$.

I když je historie hradu dobře zdokumentována ve vědecké literatuře, existuje jen několik publikací uvádějících fakta potvrzená údaji z písemných zdrojů. Ačkoli má hrad bohatou historii, v minulosti zde probíhaly jen méně zásadní archeologické výzkumy. V 19. století obdrželo Mad’arské národní muzeum v Budapešti dvě série nálezů z Koroleva $(1859,1881)$. O sto let později, v 80. letech 20. století, se uskutečnil menší výzkum poblíž centrální části hradeb vedený paleolitickou expedicí Muzea př́rody v Kyjevě. Expedice Speciálního ukrajinského vědeckého a rekonstrukčního institutu provedla na místě v 90 . letech 20. století více než dvacet sond.

Expedice Užhorodské národní univerzity začala zkoumat hrad v Korolevu v roce 2007. V letech 2007 a 2011-2014 bylo na místě realizováno pět sond a vymezeny tři výzkumné lokality $\mathrm{v}$ různých částech hradu, a to na rozloze $140 \mathrm{~m}^{2}$. Hloubka kulturní vrstvy je 1,5-5,7 m. Během výzkumu byly odkryty tři obytné místnosti s kachlovými kamny a významný soubor nálezů obsahující tisíce fragmentů keramického nádobí včetně importů, kachlů a výrobků z kůže, kostí, skla a kovu (domácí potřeby, řemeslnické nářadí, části oděvů a dekorací, medailon, žeton, textilní pečet', mince a zbraně).

Analýza stratigrafické situace a nálezů naznačuje, že opevnění Nyalábu fungovalo od 13. století do poloviny 17. století. Tato datace se rovněž shoduje s písemnými prameny. Další archeologické výzkumy a analýzy písemných dokumentů jistě poskytnou doplňující informace a zpřesňující údaje o historii tohoto klíčového opevnění.

PhD. Igor Prokhnenko, Department of History of Uzhhorod National University, sq. Narodna, 3, Uzhhorod, Ukraine, arhlabunu@ukr.net

Maria Zhylenko, Archaeological Museum of Uzhhorod National University, sq. Narodna, 3, Uzhhorod, Ukraine, arhlabunu@ukr.net

PhD. Volodimir Moizhes, Archaeological Museum of Uzhhorod National University, sq. Narodna, 3, Uzhhorod, Ukraine, arhlabunu@ukr.net 
